\title{
Involvement of Nicotinic Receptor Subtypes in the Behavioral Effects of Nicotinic Drugs in Squirrel Monkeys
}

\author{
Sarah L. Withey, ${ }^{1}$ Michelle R. Doyle, ${ }^{1,2}$ Jack Bergman, and Rajeev I. Desai \\ Preclinical Pharmacology Laboratory, McLean Hospital/Harvard Medical School, Belmont, Massachusetts \\ Received January 27, 2018; accepted May 17, 2018
}

\begin{abstract}
Evidence suggests that the $\alpha 4 \beta 2$, but not the $\alpha 7$, subtype of the nicotinic acetylcholine receptor (nAChR) plays a key role in mediating the behavioral effects of nicotine and related drugs. However, the importance of other nAChR subtypes remains unclear. The present studies were conducted to examine the involvement of $\mathrm{nAChR}$ subtypes by determining the effects of selected nicotinic agonists and antagonists in squirrel monkeys either 1) responding for food reinforcement or 2) discriminating the nicotinic agonist $(+)$-epibatidine $(0.001 \mathrm{mg} / \mathrm{kg})$ from vehicle. In food-reinforcement studies, nicotine, $(+)$-epibatidine, varenicline and cytisine all produced dose-dependent decreases in rates of food-maintained responding. The rate-decreasing effects of nicotine were antagonized by mecamylamine (nonselective), not appreciably altered by dihydro- $\beta$-erythroidine ( $\alpha 4 \beta 2$ selective), and exacerbated by the nicotinic partial agonists, varenicline and cytisine. Results from discrimination studies show that nonnicotinic drugs did not substitute for $(+)$-epibatidine, and that
\end{abstract}

except for lobeline, the nicotinic agonists produced either full $[(+)$-epibatidine, (-)-epibatidine, and nicotine] or partial (varenicline, cytisine, anabaseine, and isoarecolone) substitution for $(+)$-epibatidine. In interaction studies with antagonists differing in selectivity, (+)-epibatidine discrimination was substantively antagonized by mecamylamine, slightly attenuated by hexamethonium (peripherally restricted) or dihydro$\beta$-erythroidine, and not altered by methyllycaconitine $(\alpha 7$ selective). Varenicline and cytisine enhanced (+)-epibatidine's discriminative-stimulus effects. Correlational analysis revealed a close correspondence between relative behavioral potencies of nicotinic agonists in both studies and their published relative binding affinities at $\alpha 4 \beta 2$ and $\alpha 3 \beta 4$, but not $\alpha 7 \mathrm{nAChR}$, subtypes. Collectively, these results are consistent with the idea that the $\alpha 4 \beta 2$ and $\alpha 3 \beta 4$, but not $\alpha 7$ nAChR subtypes play a role in the behavioral effects of nicotinic agonists.

\section{Introduction}

Several pharmacological agents that may reduce nicotine's addictive effects are currently available for smoking cessation in the United States [varenicline (Chantix, Pfizer, Groton, CT) and bupropion (Wellbutrin XL, Valeant Pharmaceuticals, Bridgewater, NJ)] and Central/Eastern Europe [cytisine (Tabex, Sopharma, Sofia, Bulgaria or Desmoxan, Aflofarm Farmacja, Pabianice, Poland)] (Etter et al., 2008; Benowitz, 2010; Walker et al., 2014). Administered alone or in combination with behavioral therapy, these medications produce short-term increases in quit rates but display low antirelapse efficacy and may produce adverse effects-factors that limit their widespread clinical application (Hughes et al., 2003; Hays et al., 2008). These issues highlight the strong need for better understanding of the neurobiological and behavioral mechanisms that mediate the addictionrelated effects of nicotine, and for novel medication strategies to combat them.

This work was supported by the National Institutes of Health National Institute on Drug Abuse [Grant K01DA031231 (to R.I.D.) and Grant DA026892 (J.B.)].

${ }^{1}$ S.L.W and M.R.D contributed equally to this work.

${ }^{2}$ Current affiliation: Department of Pharmacology, University of Texas Health Science Center at San Antonio, San Antonio, Texas.

https://doi.org/10.1124/jpet.118.248070.
Several lines of evidence in rats and mice support a prominent role for $\alpha 4 \beta 2$ nicotinic acetylcholine receptor (nAChR) mechanisms in the behavioral effects of nicotine. First, the $\alpha 4 \beta 2$ selective nicotinic antagonist dihydro- $\beta$-erythroidine $(\mathrm{DH} \beta \mathrm{E})$ has been reported to block nicotine self-administration in rats (Watkins et al., 1999). Moreover, nicotine fails to maintain self-administration behavior in genetically modified mice lacking the $\beta 2$ subunit (Picciotto et al., 1998; Epping-Jordan et al., 1999), whereas selective activation of $\alpha 4^{*}$ subunits by nicotine suffices to produce rewarding effects (Tapper et al., 2004). Second, neurobiological data suggest that nicotine acts at $\alpha 4 \beta 2 \mathrm{nAChRs}$ in the ventral tegmental area to concomitantly modulate excitatory (e.g., glutamate) and inhibitory (e.g., gamma-aminobutyric acid) neurotransmission (Picciotto et al., 1998; Quarta et al., 2007), and consequently elevate and diminish dopamine levels in the nucleus accumbens (D'Souza and Markou, 2013). Finally, the $\alpha 4 \beta 2 \mathrm{nAChR}$ subtype has been implicated in the discriminative-stimulus effects of nicotine. For example, $\alpha 4 \beta 2$ subtype-selective nicotinic agonists and antagonists mimic and attenuate nicotine's effects, respectively, whereas drugs acting exclusively at other subtypes of nAChRs (e.g., $\alpha 7$ and $\alpha 3 \beta 4$ ) or other pharmacological classes (e.g., muscarinic agents) fail to engender nicotine-like stimulus effects (for review, see Smith and Stolerman, 2009). Taken together, these converging lines of evidence suggest the $\alpha 4 \beta 2$ subtype of nAChR plays a key role in nicotine's abuse-related actions. 
In addition to the $\alpha 4 \beta 2 \mathrm{nAChR}$, other subtypes of nAChRs also have been proposed to play a role in nicotine's behavioral effects (McGehee et al., 1995; Gotti et al., 1997). For example, selective antagonists at $\alpha 7$ (Markou and Paterson, 2001; Brunzell and McIntosh, 2012), $\alpha 6$ (Beckmann et al., 2015), and $\alpha 3 \beta 4$ (e.g., Glick et al., 2002; Toll et al., 2012) nAChRs have been reported to attenuate nicotine self-administration or conditioned place preference. Moreover, based on results in knockout mice, a role has been proposed for $\alpha 5$ and, in separate studies, $\alpha 6 \mathrm{nAChR}$ subtypes in the abuse-related behavioral effects of nicotine, (Pons et al., 2008; Fowler et al., 2013; Faure et al., 2014; Sanjakdar et al., 2015). Finally, the $\alpha 4 \beta 2$-selective nicotinic receptor antagonist $\mathrm{DH} \beta \mathrm{E}$ antagonized the effects of nicotine but not the $\alpha 4 \beta 2$ partial agonists varenicline and cytisine, in studies investigating their response-rate decreasing and discriminative-stimulus effects (Cunningham and McMahon, 2011; de Moura and McMahon, 2017).

The present studies were conducted to further explore the role of nAChR subtypes in the behavioral profile of nicotine by examining its effects and those of other nicotinic drugs in squirrel monkeys. First, we examined the rate-altering effects of nicotine and nicotine-related drugs on foodmaintained operant performance, and in interaction studies we examined whether nicotine's effects on operant performance are altered by pretreatment with $\mathrm{nAChR}$ antagonists or partial agonists. Next, we employed drug discrimination methodology in a separate group of squirrel monkeys to determine whether agonists that varied in efficacy and selectivity at nAChR subtypes and non-nicotinic drugs [methamphetamine (MA; indirect monoaminergic agonist), citalopram (serotonin reuptake inhibitor), atropine (muscarinic antagonist), and arecoline (muscarinic agonist)] substituted for the nicotinic agonist (+)-epibatidine. We used (+)-epibatidine discrimination because previous research suggests that its behavioral actions, like those of nicotine, are mediated primarily through $\alpha 4 \beta 2 \mathrm{nAChR}$ mechanisms, (e.g., Dukat and Glennon, 2003; Desai et al., 2016a). The nicotinic drugs studied included $\alpha 4 \beta 2 \mathrm{nAChR}$ subtype-selective ligands previously characterized as either full agonists [nicotine, (-)-epibatidine, and (+)-epibatidine] or partial agonists (isoarecolone, varenicline, cytisine, and lobeline) (Anderson and Arneric, 1994; Badio and Daly, 1994; Hahn et al., 2003; Rollema et al., 2007). Substitution tests also were conducted with the $\alpha 7 \mathrm{nAChR}$ subtype-selective agonist anabaseine (de Fiebre et al., 1995; Kem et al., 1997). Finally, we determined whether nAChR partial agonists (varenicline and cytisine) or antagonists varying in subtype selectivity attenuated (+)-epibatidine's discriminative-stimulus effects.

\section{Materials and Methods}

\section{Subjects}

Eight adult male squirrel monkeys (Saimiri sciureus; 750-950 g) were housed in stainless steel cages within a climate-controlled vivarium with a 12-hour light/dark cycle (lights on, 7:00 AM to 7:00 PM) in the McLean Hospital Animal Care Facility (licensed by the U.S. Department of Agriculture and compliant with guidelines provided by the Committee on Care and Use of Laboratory Animals of the Institute of Laboratory Animals Resources, Commission on Life Sciences, National Research Council, 2011). Except during experimental sessions, monkeys had unrestricted access to water and were fed a daily allotment of high-protein primate chow (Monkey Chow; Purina, St. Louis, MO) supplemented with fruit and multivitamins. Diets were adjusted as needed to maintain stable body weights. Behavioral experiments were conducted 5 days a week (Monday to Friday between 8:00 AM and 6:00 PM) under protocols approved by the Institutional Animal Care and Use Committee at McLean Hospital. All subjects had previously participated in behavioral studies involving drugs from differing pharmacological classes but had not participated in experiments for at least one month prior to this study.

\section{Apparatus}

During experimental sessions, subjects sat in customized Plexiglas chairs that were enclosed in ventilated, sound- and light-attenuating chambers. Subjects faced a panel with two sets of red stimulus lights and below each set, a response lever. Each lever press with a force $>0.2 \mathrm{~N}$ produced an audible click, and was recorded as a response. In food-reinforced behavior studies, a Plexiglas receptacle for liquid delivery was positioned between the response levers. A syringe pump (Model PHM-100-10; Med Associates Inc., Georgia, VT) could be operated to deliver sweetened condensed milk via Tygon tubing into the Plexiglas receptacle ( $0.15 \mathrm{ml}$ in 0.84 seconds). In drug discrimination studies, a shaved portion of the monkey's tail was secured under two brass electrodes by a small stock for the delivery of brief, low-intensity electrical stimulation $(3 \mathrm{~mA}$ for 200 milliseconds). Electrode gel was applied to the shaved area of the tail before each session to ensure low-resistance electrical contact with the electrodes. These parameters are below values associated with painful stimuli in human subjects (Vierck et al., 2008). All experimental events and data collection were recorded and controlled using commercially available interfacing equipment and operating software (MED-PC, MedState Notation; Med Associates Inc., St. Albans, VT).

\section{Food-Reinforced Behavior}

All subjects were trained to respond under a 30-response fixed ratio (FR) schedule of food reinforcement (20\% sweetened condensed milk in water). Under this schedule, the illumination of red stimulus lights on the front panel of the chair initiated the program. Completion of 30 consecutive responses on the active lever (left lever for two subjects and right lever for two subjects) turned off the stimulus lights and both triggered milk delivery and illuminated a white stimulus light above the active lever for 0.84 seconds. A 10 -second timeout (TO) period during which all stimulus lights were off and responding had no scheduled consequences was initiated by each milk delivery. Thereafter, the red stimulus lights were reilluminated and the programmed schedule contingencies were again in effect. Responses on the inactive lever were recorded but had no programmed consequences. Daily sessions were comprised of four sequential components, each consisting of a 10-minute TO period followed by a 3-minute period during which the 30-response FR, 10-second TO schedule of food reinforcement was in effect.

Drug testing in each subject began after responding was stable, defined by $<10 \%$ variability in overall response rates over 10 successive sessions. Subjects were tested twice weekly (Tuesdays and Fridays) and training sessions were conducted on the other days; no injections were given on training days. All schedule parameters and contingencies during test sessions were identical to those during training sessions. Cumulative dosing procedures were used to determine the effects of drugs; incremental doses of a drug were administered at the beginning of sequential 10-minute TO periods, permitting the evaluation of four cumulative doses during a single test session; if necessary a fifth component was initiated to allow testing of up to five cumulative doses in a single test session. The order of drug testing varied irregularly among individual subjects, and in each subject experiments with one drug were completed before the next drug was studied. For drug interaction studies, the effects of pretreatment with 
nicotinic antagonists and nicotinic partial agonists were studied by administering each pretreatment dose 10 minutes prior to the injection of the first test dose of a drug followed by incremental doses of the test drug as described previously.

\section{(+)-Epibatidine Discrimination}

The discrimination training procedure used to establish (+)-epibatidine discrimination has been described previously (Desai and Bergman, 2015; Desai et al., 2016a). Briefly, seated subjects were trained to turn off stimulus lights under a 10-response FR, 50-second TO schedule of stimulus termination. Under this schedule, the 10th lever press terminated visual stimuli associated with impending delivery of electric current to the tail ( 200 milliseconds; $3 \mathrm{~mA}$ ). At the onset of the daily session, subjects received an intramuscular injection of (+)-epibatidine $(0.001 \mathrm{mg} / \mathrm{kg})$ or saline, initiating a 10 -minute TO period during which stimulus lights were off. When stimulus lights were illuminated, current was delivered every 10 seconds (maximum of four deliveries) or until the 10-response FR response requirement was completed. Completion of the response requirement or the fourth current delivery initiated a 50-second TO. Each training session consisted of 10 presentations of the 10-response FR, 50-second TO schedule. The presession injection (drug or saline) sequence followed a double-alternation schedule (saline, saline, drug, drug, saline, saline, etc..). Testing began after subjects met criteria for stability, i.e., $>90 \%$ of responses in the first FR and overall on the injectionassociated lever during four of the last five training sessions. Thereafter, test sessions were conducted when subjects met the aforementioned criteria in two consecutive alternating [saline-drug or drug-saline] training sessions. Test sessions were identical to training sessions, with the following provisos: First, 10 successive responses on either lever turned off all stimulus lights; and second, the program of current delivery was switched off to prevent current-induced responding during testing. Test sessions occurred once or twice per week with training sessions on intervening days. Initially, tests were conducted to study the ability of single doses of nicotinic and non-nicotinic drugs to substitute for the training dose of $0.001 \mathrm{mg} / \mathrm{kg}(+)$-epibatidine. Next, drug interaction studies were conducted to determine how pretreatment with nicotinic antagonists and nicotinic partial agonists modified (+)-epibatidine's discriminative-stimulus effects. In the latter studies, single doses of a test drug were given 10 minutes prior to the injection of single doses of (+)-epibatidine $(0.0001-0.01 \mathrm{mg} / \mathrm{kg}$ ), i.e., 20 minutes prior to the test session component.

\section{Drugs}

(-)-Nicotine hydrogen tartrate [(-)-1-methyl-2-(3-pyridyl)pyrrolidine (+)-bitartrate salt], MA hydrochloride, (-)-lobeline hydrochloride, atropine sulfate, arecoline hydrobromide, hexamethonium hydrobromide, and mecamylamine hydrochloride (3-methylaminoisocamphane hydrochloride) were obtained from Sigma-Aldrich (St. Louis, MO). Citalopram hydrobromide was obtained from Lundbeck (Valby, Denmark). (+)-Epibatidine [(2R)-2-(6-chloro-3-pyridinyl)7-azabicyclo[2.2.1]heptane monohydrochloride], (-)-epibatidine [(2R)-2-(6-chloro-3-pyridinyl)-7-azabicyclo[2.2.1] heptane monohydrochloride], isoarecolone hydrochloride (1-methyl-4-acetyl-1,2,3,6-tetrahydropyridine hydrochloride), methyllycaconitine citrate (MLA) $[1 \alpha, 4$ (S),6 $\beta, 14 \alpha, 16 \beta]$-20-Ethyl-1,6,14,16-tetramethoxy-4-[[[2-(3-methyl-2,5-dioxo1-pyrrolidinyl)benzoyl]oxy]methyl]aconitane-7,8-diol citrate, and anabaseine dihydrochloride (3,4,5,6-tetrahydro-2,3'-bipyridine dihydrochloride) were obtained from the National Institute on Drug Abuse (Bethesda, MD). ( - )-Cytisine [(1R,5S)-1,2,3,4,5,6-hexahydro1,5-methano- $8 H$-pyrido[1,2-a][1,5]diazocin-8-one] and $\mathrm{DH} \beta \mathrm{E}$ hydrobromide [(2S,13bS)-2,3,5,6,8,9,10,13-octahydro-2-methoxy-1H,12H-benzo[i]pyrano[3,4-g]indolizin-12-one hydrobromide] were obtained from Tocris Bioscience (Minneapolis, MN). Varenicline [6,7,8,9-tetrahydro6,10-methano-6H-pyrazino[2,3-hour][3]benzazepine] was generously donated by Dr. Hans Rollema at Pfizer Global Research and Development (Rollema Biomedical Consulting, Mystic, CT). All drugs were dissolved in sterile $0.9 \%$ saline solution or water and were administered by intramuscular injection (volume $\leq 0.3 \mathrm{ml}$ ). Drugs tested under the schedule of food-maintained behavior were administered using cumulative dosing procedures, whereas drugs tested in (+)-epibatidine discrimination studies were administered as single doses. The $\mathrm{pH}$ of nicotine was adjusted as needed to $\mathrm{pH} 7.0$ with sodium hydroxide $(0.1 \mathrm{~N})$. Doses of each drug are expressed in terms of the free base.

\section{Data Analysis}

Food-Reinforced Behavior. Response rates were calculated for each component by dividing the total number of responses on the active lever by the duration of the component excluding the TO periods. Response rates were not significantly altered by vehicle injection, and therefore baseline values for each subject were determined by averaging data from all noninjection (training sessions) and vehicle injection control sessions throughout the study. The effect of each dose of a drug was calculated for individual subjects as a percentage of the mean control response rate. Grouped data were analyzed using repeatedmeasures one-way analysis of variance followed by Dunnett's $t$ test (Prism version 5.0; GraphPad, La Jolla, CA).

(+)-Epibatidine Discrimination. The percentage of (+)-epibatidineassociated responding was calculated by dividing the number of responses on the drug lever by the total number of responses on both levers. Response rates were calculated for each session by dividing the total number of responses by the duration of the session excluding TO periods. If the mean response rate in a test session was $<0.2$ responses per second, data from that session were excluded from further analysis. Mean results for vehicle and each dose of a drug were calculated by averaging data for the four subjects. Complete, partial, and no substitution for (+)-epibatidine was defined as $\geq 90 \%, 31 \%-89 \%$, and $\leq 30 \%$ of total responses on the (+)-epibatidine-associated lever, respectively.

ED $_{50}$ Calculations. The dose of a drug needed to produce 50\% reduction in response rate (food-reinforced behavior) and engender $50 \%(+)$-epibatidine lever responding $\left(\mathrm{ED}_{50}\right)$ was calculated for individual subjects by interpolation of the linear portion of the doseresponse curve. The mean $\mathrm{ED}_{50}$ value ( \pm S.E.M.) for each drug was determined by averaging $\mathrm{ED}_{50}$ values for individual subjects. In pretreatment studies, modification of nicotine's effects on operant response rate or (+)-epibatidine discrimination was analyzed by comparing the $\mathrm{ED}_{50}$ values for nicotine and (+)-epibatidine (respectively) alone and in the presence of each dose of the test drug.

Pearson's Product-Moment Correlation Coefficient Calculation. Correspondence between the effects of drugs on behavior and competition receptor binding studies was examined by comparing the relative potency of nicotinic drugs in the present experiments (i.e., $\mathrm{ED}_{50}$ values divided by the $\mathrm{ED}_{50}$ value for nicotine alone) and their published relative affinities for binding $\alpha 4 \beta 2, \alpha 7$, and $\alpha 3 \beta 4$ nicotinic receptors in vitro ( $K_{\mathrm{i}}$ values divided by the $K_{\mathrm{i}}$ value for nicotine alone). Relative affinity values for each drug were obtained from previously published radioligand binding experiments in rat brain. Affinity values from multiple studies in rat brain were averaged, and whenever possible were taken from studies using $\left[{ }^{3} \mathrm{H}\right]$ nicotine binding for $\alpha 4 \beta 2$ receptor subtype, $\left[{ }^{125} \mathrm{I}\right]-\alpha$-bungarotoxin binding for the $\alpha 7$ nicotinic receptor subtype, and $\left[{ }^{3} \mathrm{H}\right]$ epibatidine binding for the $\alpha 3 \beta 4$ nicotinic receptor subtype. The Pearson's product-moment correlation coefficient of these values was calculated to determine the relationship between relative behavioral potency and relative binding affinity at each nAChR subtype.

\section{Results}

\section{Food-Reinforced Behavior}

Control Performance. Rates of food-reinforced responding were stable over the course of the present experiments, with average response rates for individual subjects ranging from 4.16 to 6.0 responses per second (Table 1 ). 
TABLE 1

Mean rates of responding (responses per second) under the 30-response FR schedule of food-reinforced behavior for individual monkeys during noninjection and vehicle control sessions $(n)$

\begin{tabular}{lcc}
\hline Monkey & $n$ & Average Responses per Second \pm S.E.M. \\
\hline Ss 9 & 50 & $5.23 \pm 0.12$ \\
Ss 80 & 34 & $5.61 \pm 0.82$ \\
Ss 81 & 50 & $6.0 \pm 0.15$ \\
Ss 106 & 49 & $4.16 \pm 0.08$ \\
\hline
\end{tabular}

Effect of Nicotinic Agonists and Antagonists Alone. The nicotinic agonists nicotine $(0.032-0.32 \mathrm{mg} / \mathrm{kg})$ and $(+)-$ epibatidine $(0.000032-0.001 \mathrm{mg} / \mathrm{kg}$ ) and the nicotinic partial agonists varenicline $(0.0032-0.1 \mathrm{mg} / \mathrm{kg})$ and cytisine $(0.01-1.0 \mathrm{mg} / \mathrm{kg})$ all produced dose-dependent and, at high doses, significant decreases in response rates under the FR schedule of food reinforcement $(P<0.05$; Fig. 1$)$. The rank order of potency based on the $\mathrm{ED}_{50}$ values was $(+)$-epibatidine $>$ varenicline $>$ nicotine $\approx$ cytisine (Table 2). In contrast, the nicotinic antagonists mecamylamine $(0.032-1.0 \mathrm{mg} / \mathrm{kg})$ and $\mathrm{DH} \beta \mathrm{E}(0.032-0.56 \mathrm{mg} / \mathrm{kg})$ did not significantly alter rates of responding (Fig. 1). The effects of higher doses of mecamylamine and $\mathrm{DH} \beta \mathrm{E}$ alone were not determined to preclude potential adverse side effects.

Effects of Pretreatment with Nicotinic Antagonists. Mecamylamine $(0.1-1.0 \mathrm{mg} / \mathrm{kg})$ antagonized the effects of cumulatively administered nicotine on response rate, as indicated by dose-dependent rightward shifts of the nicotine dose-effect function and corresponding significant changes in
$\mathrm{ED}_{50}$ values (Fig. 2A, top left panel; Table 3). To assess the specificity with which mecamylamine antagonized nicotine's effects on response rate, we examined its ability to modify the rate-decreasing effects of the indirect monoaminergic agonist MA. Like nicotine, MA alone produced dose-dependent and significant decreases in the rate of responding for food reinforcement (Fig. 2A, top right panel). Overall, these effects of MA were not attenuated by any pretreatment dose of mecamylamine; in fact, the combination of $1.0 \mathrm{mg} / \mathrm{kg}$ mecamylamine and the intermediate dose of $0.1 \mathrm{mg} / \mathrm{kg}$ MA doses that were alone without effect significantly decreased foodmaintained responding, resulting in a corresponding decrease in $\mathrm{ED}_{50}$ value compared with $\mathrm{MA}$ alone (Fig. $2 \mathrm{~A}$, top right panel; Table 3). In contrast to mecamylamine, administration of $\mathrm{DH} \beta \mathrm{E}(0.1-0.56 \mathrm{mg} / \mathrm{kg})$ did not substantively modify nicotine's effects on response rate (Fig. 2A, bottom left panel), and the $\mathrm{ED}_{50}$ values for nicotine's effects on rates of responding after pretreatment with $\mathrm{DH} \beta \mathrm{E}$ were not significantly different from the $\mathrm{ED}_{50}$ value of nicotine alone (Table 3). In additional studies, the highest dose of $\mathrm{DH} \beta \mathrm{E}(0.56 \mathrm{mg} / \mathrm{kg})$ also failed to significantly alter the rate-decreasing effect of (+)-epibatidine, reflected both in overlapping dose-effect curves and comparable $\mathrm{ED}_{50}$ values (Fig. $2 \mathrm{~A}$, bottom right panel; Table 3).

Effects of Pretreatment with Varenicline and Cytisine. Doses of varenicline and cytisine that did not decrease response rates alone (Fig. 1) did serve to alter the effects of nicotine. Thus, pretreatment with $0.032 \mathrm{mg} / \mathrm{kg}$ of varenicline produced a leftward shift of the nicotine dose-effect curve,

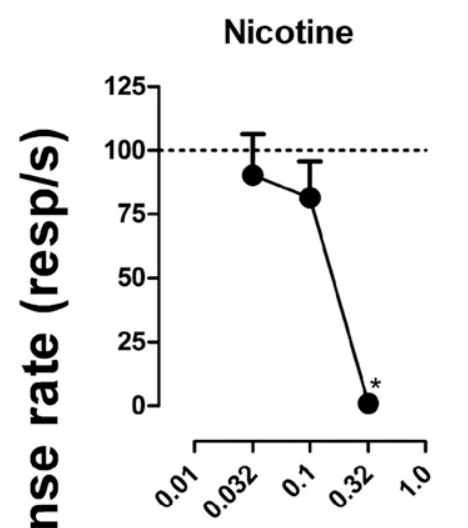

\section{Cytisine}

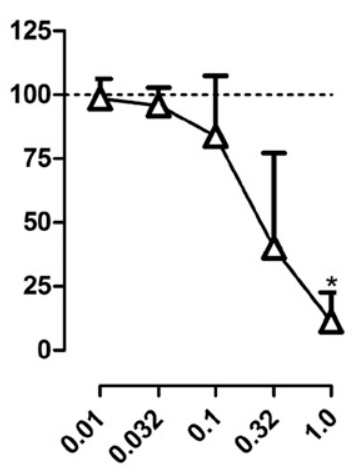

(+)-Epibatidine

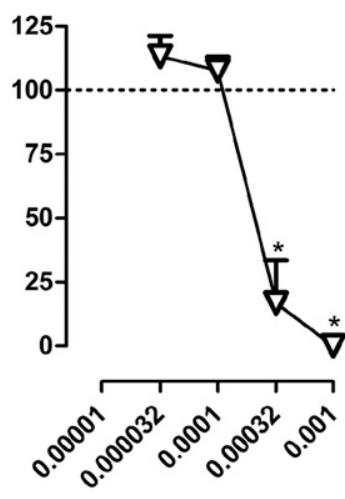

Mecamylamine

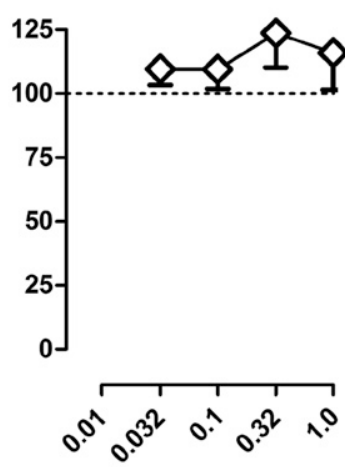

Varenicline

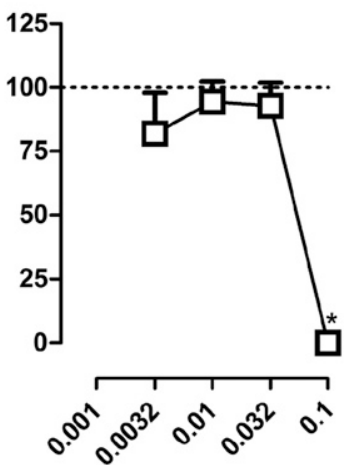

$\mathrm{DH} \beta \mathrm{E}$

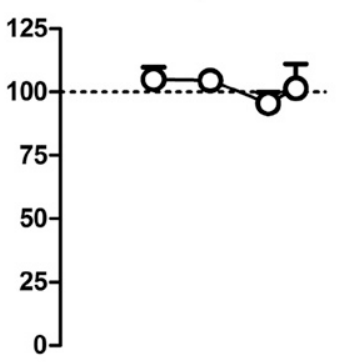

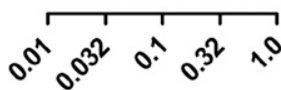

Fig. 1. Effects of nicotinic agonists [(+)-epibatidine: (+)-Epi; nicotine: Nic; varenicline: Var; and cytisine: Cyt] and antagonists (mecamylamine: $\mathrm{Mec}$; and $\mathrm{DH} \beta \mathrm{E}$ ) on schedule-controlled behavior in squirrel monkeys. Each data point represents the average effect determined in four monkeys. Dashed line represents effects of vehicle; * indicates significant difference from vehicle levels; Dunnett's $t$ test, $P<0.05$, on mean values derived from the main effect of dose. [(+)-Epi, Nic, Var, Cyt: $\mathrm{Fs}_{3-18} \geq 3.82$; ps $\left.<0.05\right]$; Mec, $\mathrm{DH} \beta \mathrm{E}:\left(\mathrm{Fs}_{4-15} \leq 0.80 ; \mathrm{ps}>0.05\right)$. Abscissa: cumulative drug dose (milligrams per kilogram). Ordinates: response rates expressed as a percentage of the average rate obtained during vehicle and noninjection test sessions.

\section{Drug dose $(\mathrm{mg} / \mathrm{kg})$}




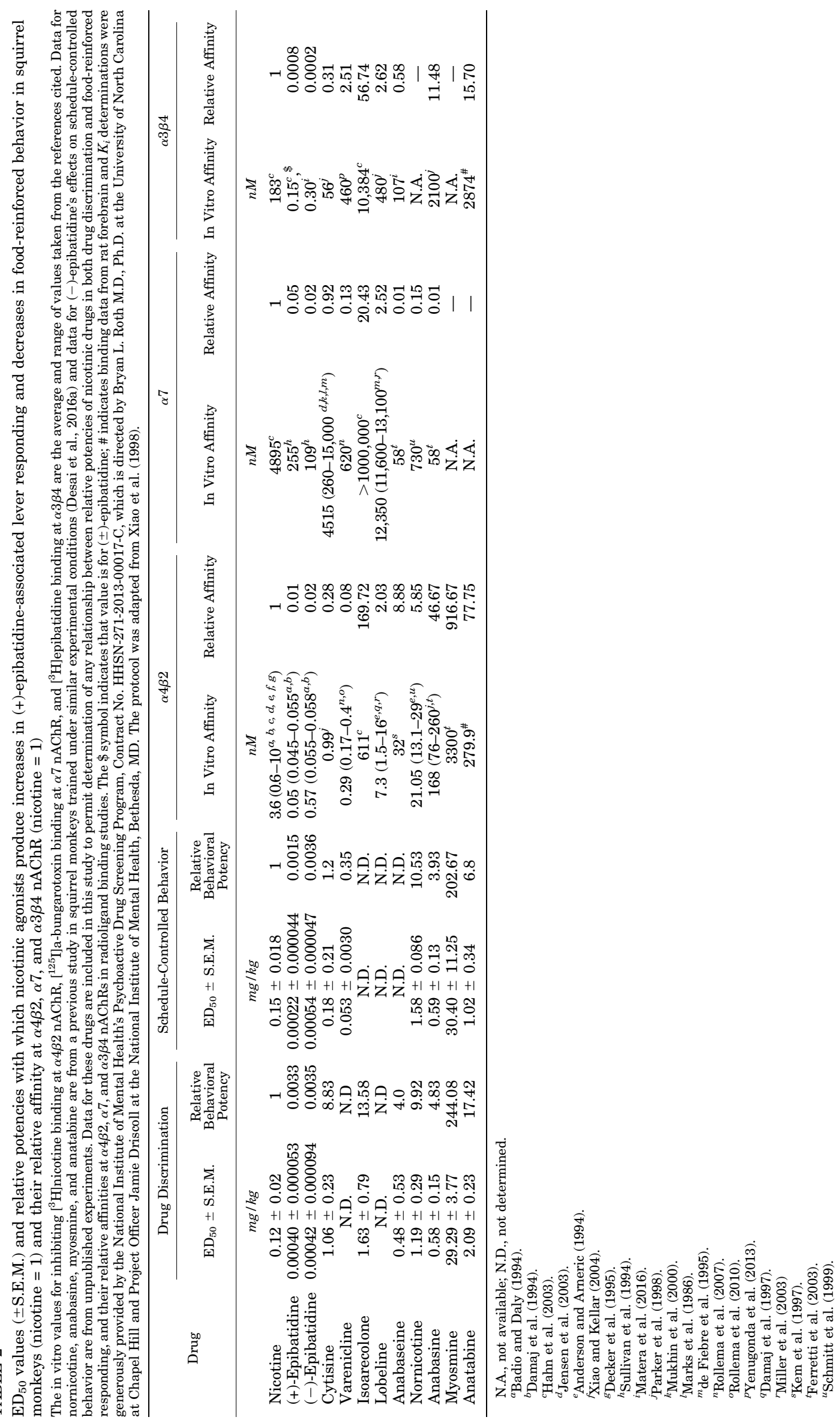



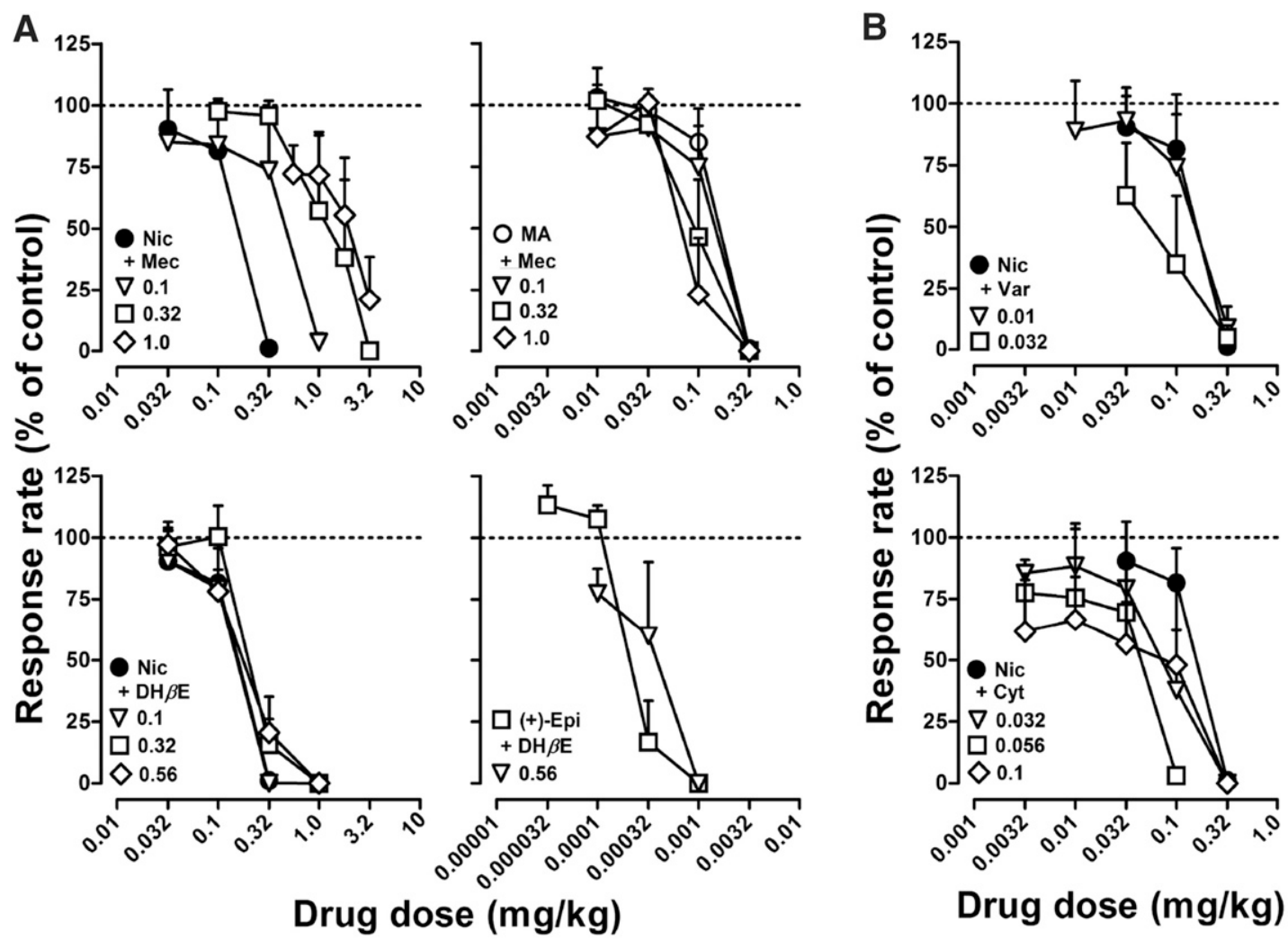

Fig. 2. (A) Dose-effect functions of nicotine alone or after pretreatment with the nicotinic antagonists mecamylamine [(Mec) top left panel] and DH $\beta E$ (bottom left panel), and dose-effect functions of MA alone or after pretreatment with the nicotinic antagonist mecamylamine (top right panel) and (+)-epibatidine [(+)-Epi] alone or after pretreatment with $\mathrm{DH} \beta \mathrm{E}$ (bottom right panel) on schedule-controlled behavior in squirrel monkeys. (B) Doseeffect functions of nicotine alone or after pretreatment with varenicline [(Var) top panel] and cytisine [(Cyt) bottom panel]. Results are presented as mean percent control ( \pm S.E.M.). Abscissa: cumulative drug dose (milligrams per kilogram). Ordinates: response rates expressed as a percentage of the average rate obtained during vehicle and noninjection test sessions.

resulting in an approximately 2-fold decrease in nicotine's $\mathrm{ED}_{50}$ value (Fig. $2 \mathrm{~B}$, top panel; Table 3 ). Similarly, cytisine $(0.032-0.1 \mathrm{mg} / \mathrm{kg})$, enhanced the rate-decreasing effects of nicotine. This was evident in a leftward shift in the nicotine dose-effect curve following 0.032 and $0.056 \mathrm{mg} / \mathrm{kg}$ cytisine and a downward shift in the nicotine dose-effect curve following $0.1 \mathrm{mg} / \mathrm{kg}$ cytisine (Fig. $2 \mathrm{~B}$, bottom panel), resulting from the effects of $0.1 \mathrm{mg} / \mathrm{kg}$ cytisine alone (Fig. 1). Correspondingly, pretreatment with $0.032-0.1 \mathrm{mg} / \mathrm{kg}$ cytisine resulted in a 3 - to 6 -fold decrease in the $\mathrm{ED}_{50}$ value for the rate-decreasing effects of nicotine (Table 3 ).

\section{(+)-Epibatidine Discrimination}

Consistent with our previous observations (Desai and Bergman, 2015; Desai et al., 2016a), reliable discriminativestimulus control by $0.001 \mathrm{mg} / \mathrm{kg}(+)$-epibatidine was maintained in all four subjects throughout the present study (Fig. 3, top panel). No significant changes in response rates were observed following administration of $0.001 \mathrm{mg} / \mathrm{kg}$ $(+)$-epibatidine compared with vehicle values (Fig. 3, bottom panel). There was no significant change in (+)-epibatidine's (0.0001-0.001 $\mathrm{mg} / \mathrm{kg}$ ) discriminative-stimulus effects or response rates over the length of the study ( $>24$ months). The $\mathrm{ED}_{50}$ values ( \pm S.E.M.) for (+)-epibatidine's discriminativestimulus effects were $0.00031 \pm 0.00011$ versus $0.00055 \pm$ 0.000024 at the beginning and end of the study, respectively.
Thus, discrimination and response rate data for (+)-epibatidine at the beginning and end of these experiments were averaged to provide control values for all analyses and graphic presentations.

Effects of Nicotinic Agonists. The (+)- and (-)enantiomers of epibatidine $(0.0001-0.001 \mathrm{mg} / \mathrm{kg})$ produced dose-dependent increases in responding on the (+)-epibatidineassociated lever, with full substitution occurring at the $0.001 \mathrm{mg} / \mathrm{kg}$ dose of (+)- and (-)-epibatidine in all subjects (Fig. 3, top panel). Nicotine $(0.01-0.32 \mathrm{mg} / \mathrm{kg})$ also produced dose-dependent substitution for $0.001 \mathrm{mg} / \mathrm{kg}$ (+)-epibatidine, with full substitution following intramuscular administration of $0.32 \mathrm{mg} / \mathrm{kg}$ dose of nicotine (Fig. 3, top panel). In contrast, the nicotinic partial agonists varenicline $(0.01-0.18 \mathrm{mg} / \mathrm{kg})$, cytisine $(0.0032-3.2 \mathrm{mg} / \mathrm{kg})$, anabaseine $(0.032-1.0 \mathrm{mg} / \mathrm{kg})$, and isoarecolone (0.32-3.2 mg/kg) produced partial substitution (Fig. 3, top panel). Maximum responding on the (+)-epibatidine lever was observed following administration of $0.032 \mathrm{mg} / \mathrm{kg}$ varenicline $(46 \% \pm 26 \%), 1.8 \mathrm{mg} / \mathrm{kg}$ cytisine $(60 \% \pm 23 \%), 3.2 \mathrm{mg} / \mathrm{kg}$ isoarecolone $(51 \% \pm 21 \%)$, and $1.0 \mathrm{mg} / \mathrm{kg}$ anabaseine $(72 \% \pm$ $16 \%$ ). These data typically reflect effects that somewhat varied among individual monkeys, i.e., two subjects produced greater than $80 \%$ responding on the $(+)$-epibatidine lever, whereas the remaining two monkeys did not generalize for (+)-epibatidine discrimination. The $\mathrm{nAChR}$ partial agonist, lobeline, did not generalize for $(+)$-epibatidine $(8 \% \pm 5 \%)$. The effects of higher doses of each of these nicotinic partial agonists were not 
TABLE 3

Doses of nicotine alone and after pretreatment with mecamylamine, $\mathrm{DH} \beta \mathrm{E}$, varenicline, and cytisine which were required to produce $50 \%$ decreases in food-reinforced behavior. Doses of (+)-epibatidine and MA alone after treatment with $\mathrm{DH} \beta \mathrm{E}$ and mecamylamine which were required to produce $50 \%$ decreases in food-reinforced behavior, respectively

\begin{tabular}{|c|c|}
\hline Treatment & $\mathrm{ED}_{50}$ value \pm S.E.M. $\mathrm{mg} / \mathrm{kg}$ \\
\hline Nicotine Alone & $0.15 \pm 0.018$ \\
\hline$+0.1 \mathrm{mg} / \mathrm{kg}$ Mecamylamine & $0.40 \pm 0.11^{*}$ \\
\hline$+0.32 \mathrm{mg} / \mathrm{kg}$ Mecamylamine & $0.94 \pm 0.26^{*}$ \\
\hline + $1.0 \mathrm{mg} / \mathrm{kg}$ Mecamylamine & $1.67 \pm 1.20^{*}$ \\
\hline$+0.1 \mathrm{mg} / \mathrm{kg} \mathrm{DH} \beta \mathrm{E}$ & $0.11 \pm 0.033$ \\
\hline$+0.32 \mathrm{mg} / \mathrm{kg} \mathrm{DH} \beta \mathrm{E}$ & $0.19 \pm 0.054$ \\
\hline$+0.56 \mathrm{mg} / \mathrm{kg} \mathrm{DH} \beta \mathrm{E}$ & $0.17 \pm 0.0067$ \\
\hline$+0.01 \mathrm{mg} / \mathrm{kg}$ Varenicline & $0.13 \pm 0.046$ \\
\hline$+0.032 \mathrm{mg} / \mathrm{kg}$ Varenicline & $0.093 \pm 0.035^{*}$ \\
\hline$+0.032 \mathrm{mg} / \mathrm{kg}$ Cytisine & $0.048 \pm 0.037^{*}$ \\
\hline$+0.056 \mathrm{mg} / \mathrm{kg}$ Cytisine & $0.027 \pm 0.0047^{*}$ \\
\hline$+0.1 \mathrm{mg} / \mathrm{kg}$ Cytisine & $0.057 \pm 0.058^{*}$ \\
\hline (+)-Epibatidine Alone & $0.00022 \pm 0.000044$ \\
\hline$+0.56 \mathrm{mg} / \mathrm{kg} \mathrm{DH} \beta \mathrm{E}$ & $0.00032 \pm 0.00014$ \\
\hline MA Alone & $0.14 \pm 0.032$ \\
\hline$+0.1 \mathrm{mg} / \mathrm{kg}$ Mecamylamine & $0.12 \pm 0.025$ \\
\hline + $0.32 \mathrm{mg} / \mathrm{kg}$ Mecamylamine & $0.086 \pm 0.022$ \\
\hline + $1.0 \mathrm{mg} / \mathrm{kg}$ Mecamylamine & $0.072 \pm 0.022 *$ \\
\hline
\end{tabular}

determined because in the present or previous studies 0.25 or 0.5 log-unit higher doses either markedly disrupted responding or produced untoward effects in squirrel monkeys (Desai and Bergman, 2014; Desai et al., 2016a). Based on the mean $\mathrm{ED}_{50}$ values, the rank order of potency of drugs that produced epibatidine-like effects was $(+)$-epibatidine $\approx(-)$-epibatidine $>$ nicotine $>$ cytisine $>$ isoarecolone $>$ anabaseine (Table 1 ). Response rates were not significantly altered by any dose of (+)-epibatidine, (-)-epibatidine, varenicline, cytisine, anabaseine, isoarecolone, or lobeline, although nicotine did produce a significant increase in rates of responding at $0.1 \mathrm{mg} / \mathrm{kg}$ (Fig. 3 , bottom panel).

Effects of Non-Nicotinic Drugs. At the doses examined, MA (0.032-0.56 mg/kg; monoaminergic psychomotor stimulant), atropine (0.01-0.1 mg/kg; muscarinic antagonist), arecoline (0.01-0.1 $\mathrm{mg} / \mathrm{kg}$; partial muscarinic agonist), and citalopram $(0.32-10 \mathrm{mg} / \mathrm{kg}$; serotonin-selective reuptake inhibitor) did not substitute for (+)-epibatidine (Fig. 3, top panel). Except for a small decrease in responding produced by the highest doses of MA $(0.56 \mathrm{mg} / \mathrm{kg})$ and arecoline $(0.1 \mathrm{mg} / \mathrm{kg})$, none of the drugs produced significant changes in rates of responding (Fig. 3, bottom panel).

Effects of Pretreatment with Nicotinic Antagonists. Administration of $\mathrm{nAChR}$ antagonists prior to saline produced limited responding on the (+)-epibatidine-associated lever and did not significantly alter response rates compared with control values (Fig. 4). In drug interaction studies, pretreatment with the nonselective nicotinic antagonist mecamylamine $(0.032-0.32 \mathrm{mg} / \mathrm{kg})$ dose dependently antagonized the discriminative-effects of (+)-epibatidine (Fig. 4, top panel; Table 4). Thus, a 3 -fold higher dose of (+)-epibatidine was required to produce full substitution after pretreatment with $0.1 \mathrm{mg} / \mathrm{kg}$ mecamylamine, whereas doses of $(+)$-epibatidine up to $0.0056 \mathrm{mg} / \mathrm{kg}$ failed to produce any (+)-epibatidine-like effects after pretreatment with $0.32 \mathrm{mg} / \mathrm{kg}$ mecamylamine (Fig. 4, top panel; Table 4). In contrast, the nAChR subtype-selective antagonists were relatively ineffective in attenuating (+)-epibatidine's discriminative-stimulus effects. The two highest doses of the $\alpha 4 \beta 2$-selective nicotinic antagonist $\mathrm{DH} \beta \mathrm{E}(0.32$ and $0.56 \mathrm{mg} / \mathrm{kg})$ produced only an approximately 2-fold rightward shift in the (+)-epibatidine doseresponse curve and a corresponding decrease in potency, whereas pretreatment with a 10-fold range of doses of the $\alpha 7$-selective nicotinic antagonist MLA $(0.01-0.1 \mathrm{mg} / \mathrm{kg})$ was without effect (Fig. 4, top panel; Table 4). Finally, pretreatment with the highest dose of hexamethonium $(5.6 \mathrm{mg} / \mathrm{kg})$, a nonselective peripherally acting nicotinic antagonist, produced a slight rightward shift in the (+)-epibatidine-dose response curve resulting in a small but significant increase in the $\mathrm{ED}_{50}$ value of (+)-epibatidine (Fig. 4, top panel; Table 4). There were no decreases in response rates following (+)epibatidine in combination with any of the antagonists tested (Fig. 4, bottom panel).

Effects of Pretreatment with Varenicline and Cytisine. The effects of pretreatment with nicotinic partial agonist varenicline $(0.001-0.1 \mathrm{mg} / \mathrm{kg})$ or cytisine $(0.032-1.0 \mathrm{mg} / \mathrm{kg})$ on (+)-epibatidine discrimination are shown in Fig. 5. Low-tointermediate doses of varenicline $(0.001-0.032 \mathrm{mg} / \mathrm{kg})$ had no significant effect on (+)-epibatidine discrimination (Fig. 5, top left panel; Table 4). Administration of the highest dose of $0.1 \mathrm{mg} / \mathrm{kg}$ varenicline produced an apparent leftward and upward shift in the (+)-epibatidine dose-response function (Fig. 5, top left panel). Thus, pretreatment with this dose of varenicline prior to injections of the lowest two doses of (+)-epibatidine $(0.00001$ or $0.000032 \mathrm{mg} / \mathrm{kg})$ resulted in intermediate-to-high levels of responding on the (+)-epibatidineassociated lever, precluding determination of potency values.

Cytisine produced dose-dependent leftward shifts in (+)epibatidine's dose-response curves (Fig. 5, top right panel; Table 4). Thus, the lowest pretreatment dose of $0.032 \mathrm{mg} / \mathrm{kg}$ cytisine did not modify (+)-epibatidine's discriminativestimulus effects, whereas pretreatment with higher doses of cytisine $(0.1$ or $1.0 \mathrm{mg} / \mathrm{kg})$ produced a leftward shift in (+)epibatidine's dose-response curve and a corresponding decrease in $\mathrm{ED}_{50}$ values (Fig. 5, top right panel; Table 4). As with varenicline, the highest pretreatment dose of cytisine $(1.0 \mathrm{mg} / \mathrm{kg})$ prior to injections of all doses of (+)-epibatidine produced $>50 \%$ responding on the $(+)$-epibatidine-associated lever, precluding determination of $\mathrm{ED}_{50}$ values (Fig. 5; Table $4)$. There were no decreases in response rates following (+)epibatidine in combination with varenicline or cytisine (Fig. 5, bottom panel).

\section{Discussion}

The present studies were conducted to elucidate the role of nAChR subtypes in the behavioral effects of nicotinic ligands in squirrel monkeys. Results show that nicotine and the enantiomers of epibatidine engendered dose-dependent and full substitution for (+)-epibatidine's stimulus effects and produced dose-dependent decreases in rates of food-maintained behavior. Unlike the well-known stereoselective actions of nicotine (e.g., Goldberg et al., 1989), the two enantiomers of epibatidine produced the same behavioral effects with equal potency. These results agree with previous findings (Damaj et al., 1994; Smith and Stolerman, 2009; Desai and Bergman, 2014) and are consistent with the nonstereoselective binding 


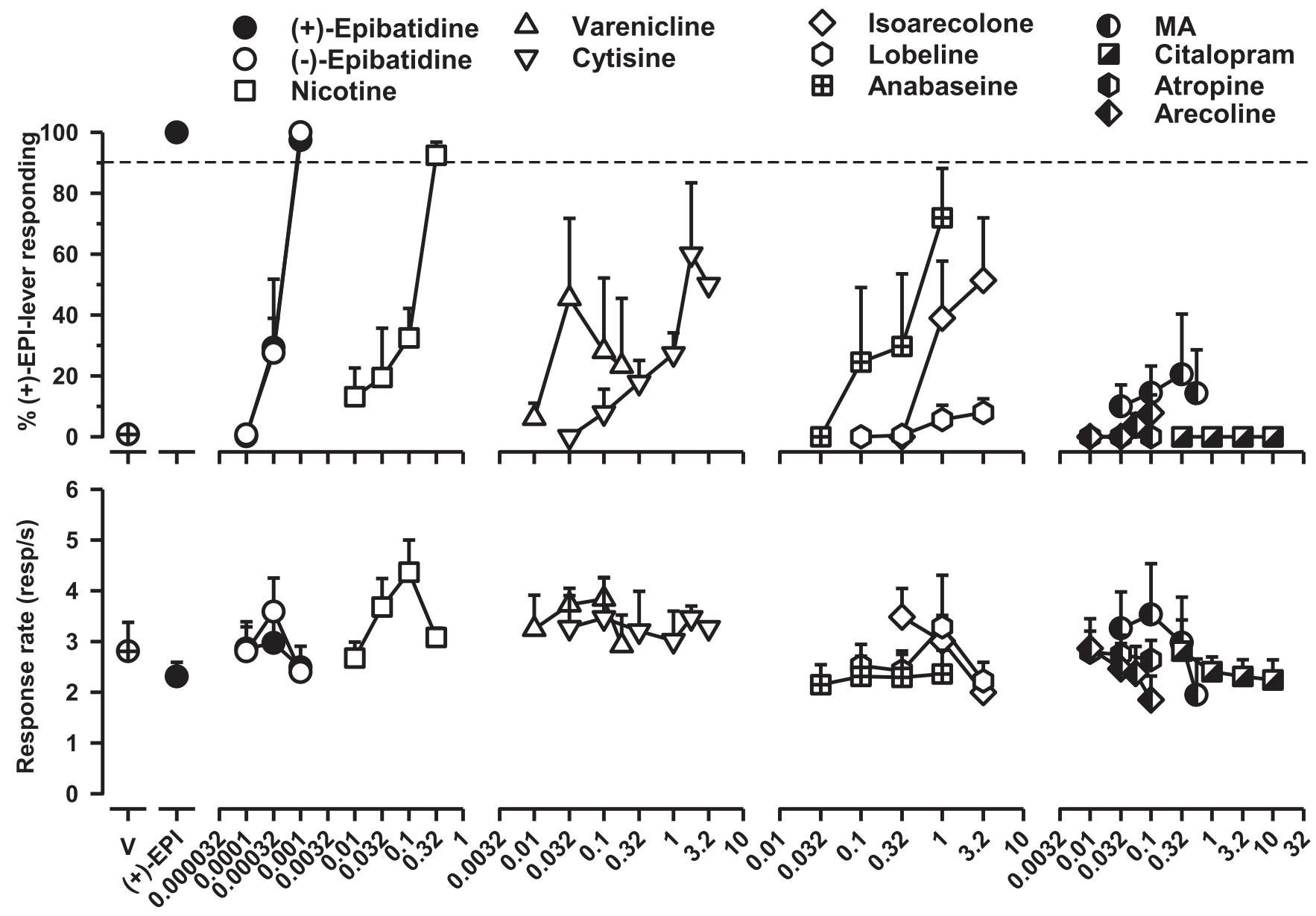

\section{Drug Dose $(\mathrm{mg} / \mathrm{kg})$}

Fig. 3. Effects of the nicotinic ligands [(+)-epibatidine, (-)-epibatidine, nicotine, varenicline, cytisine, isoarecolone, lobeline, and anabaseine] and nonnicotinic drugs [MA, citalopram, atropine, and arecoline] on percent (+)-epibatidine-lever responding (top panel) and response rates (bottom panel) in squirrel monkeys trained to discriminate $0.001 \mathrm{mg} / \mathrm{kg}(+)$-epibatidine from saline. Each data point represents the average ( \pm S.E.M.) of effects in four subjects tested at each dose. Abscissa: drug dose (milligrams per kilogram). Ordinates: top panel: percentage (+)-epibatidine-lever responding; bottom panel: response rate.

profile displayed by the two optical isomers of epibatidine at $\alpha 4 \beta 2$ nAChR subtypes (e.g., Dukat and Glennon, 2003). The nAChR ligands varenicline, cytisine, isoarecolone, and anabaseine also engendered dose-related (+)-epibatidine-like discriminative-stimulus effects but the maximum effect was less than that of nicotine or (+)-epibatidine. These results along with the dose-dependent decreases in food-maintained responding produced by varenicline and cytisine are consistent with those from several studies in which, depending on the experimental conditions, one or more of these drugs either partially or fully reproduced the behavioral effects of nicotine (e.g., LeSage et al., 2009; Smith and Stolerman, 2009; Jutkiewicz et al., 2011; Cunningham et al., 2012; Desai and Bergman, 2015; Desai et al., 2016a; de Moura and McMahon, 2017). The effects of these compounds are consistent with their in vitro classification as nicotinic partial agonists at the $\alpha 4 \beta 2$ nAChR subtype (Kem et al., 1997; Hahn et al., 2003; Shoaib, 2006; Rollema et al., 2010). However, varenicline, cytisine, and anabaseine also have activity at other nAChR subtypes, which may have interfered with the ability of higher doses to fully express $\alpha 4 \beta 2$-mediated agonist-like behavioral effects.
All nAChR agonists and partial agonists tested in both behavioral studies decreased food-reinforced responding and produced (+)-epibatidine-like stimulus effects over a similar range of doses, and with the exception of cytisine at similar $\mathrm{ED}_{50}$ values (Table 2). On the other hand, nicotinic full or partial agonists that produced significant decreases in rates of responding under the schedule of food reinforcement had little or no effect on rates of responding under the stimulus-termination schedule. This agrees with previous studies showing that the potency of nicotine (Spealman et al., 1981) and other drug classes-i.e., benzodiazepines (Barrett, 1976) and opioids (Bergman and Warren, 1989) - to decrease responding may differ when behaviors are maintained by dissimilar consequences. For example, although nicotine demonstrated similar behavioral effects under schedules of both food presentation and stimulus-shock termination, the potency of nicotine to decrease rates of responding was higher under schedules of food presentation than under schedules of stimulus-shock termination (Spealman et al., 1981).

We found no overlap in the discriminative-stimulus effects of (+)-epibatidine and the partial nAChR agonist lobeline, 

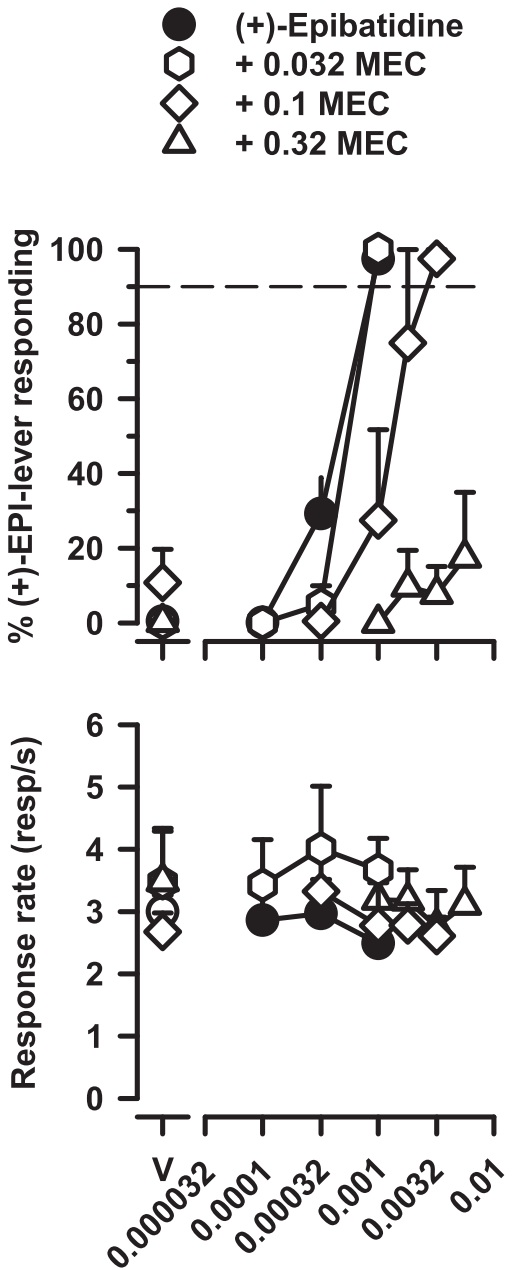
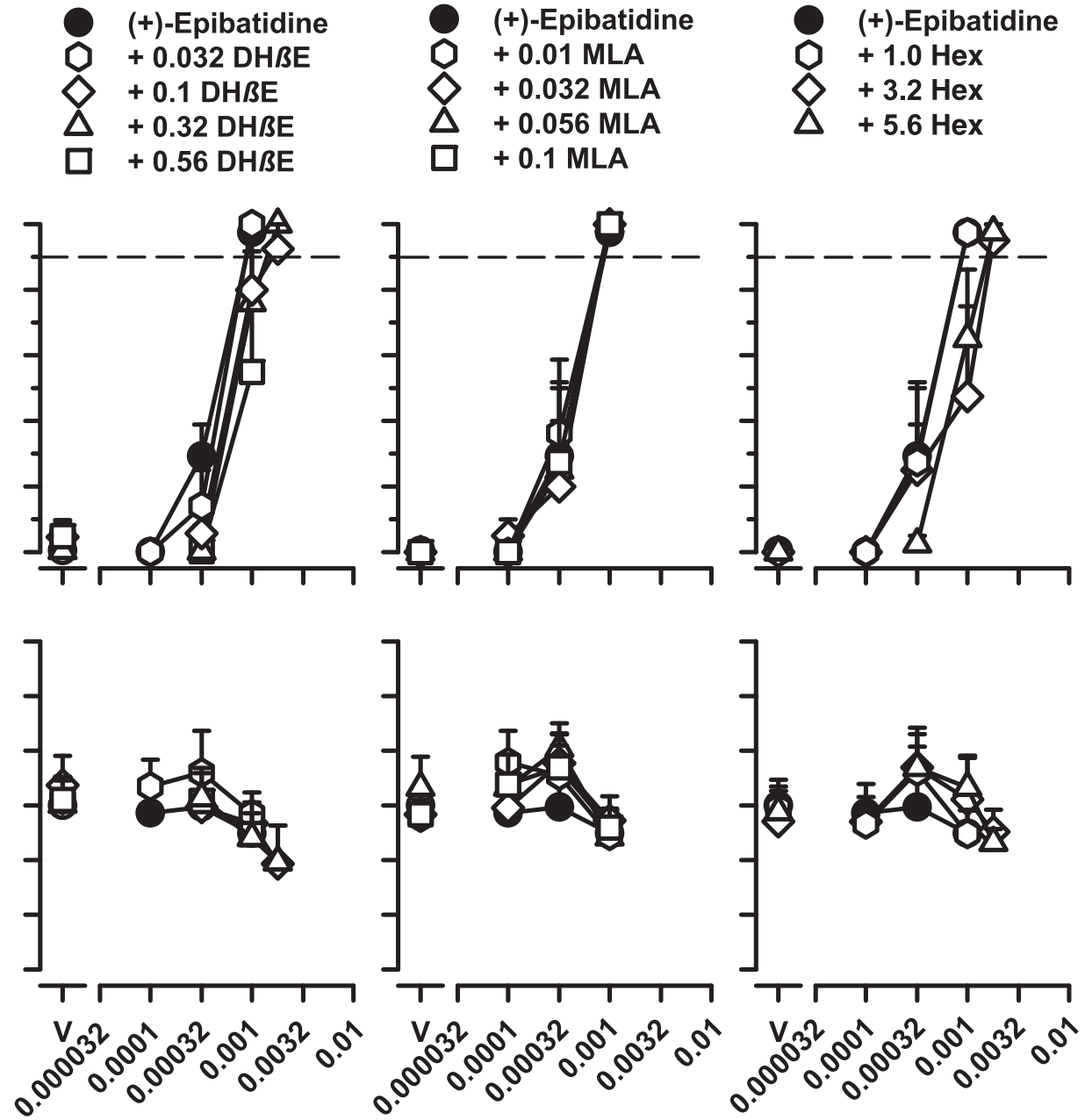

\section{Drug Dose $(\mathrm{mg} / \mathrm{kg})$}

Fig. 4. Dose-effect functions of (+)-epibatidine in squirrel monkeys trained to discriminate $0.001 \mathrm{mg} / \mathrm{kg}(+)$-epibatidine from saline either alone (filled circles) or after several pretreatment doses (10 minutes) of the nicotinic antagonists mecamylamine (MEC), DH $\beta E$, MLA, and hexamethonium (HEX). Effects on percent (+)-epibatidine-lever responding (top panels) and effects on response rates (bottom panel) are shown. Abscissa: drug dose (milligrams per kilogram). Ordinates: top panel: percentage (+)-epibatidine-lever responding; bottom panel: response rate.

consistent with the absence of nicotine-like discriminative effects in prior studies. Although the reasons for these findings are unclear, non-nicotinic pharmacological actions of lobeline (e.g., monoaminergic activity) might obscure the expression of its nicotinic activity (e.g., Stolerman et al., 1995; Dwoskin and Crooks, 2002; Harrod et al., 2003; Desai and Bergman, 2014). Similarly, our data with arecoline, atropine, and citalopram agree with previous results showing that muscarinic and serotoninergic mechanisms do not contribute appreciably to the behavioral effects of nicotinic agonists (Smith and Stolerman, 2009). With regard to MA, although the monoaminergic stimulant did not engender (+)-epibatidine-like discriminativestimulus effects in the present experiments, we previously found that both (+)-epibatidine and nicotine fully substitute for MA in MA-trained subjects (Desai and Bergman, 2010; 2014). Although latter findings suggest that the discriminativestimulus effects of MA and nicotinic drugs share common features, the asymmetric pattern of cross-generalization also suggests that there are important differences between the stimulus complexes of these drugs. The reason for this asymmetric generalization between nicotinic drugs and MA remains unclear in the absence of additional data, but may be related to MA providing a weak cholinergic stimulus or in terms of nicotinic drugs acting indirectly as weak dopamine agonists.

As expected, the nonselective nAChR antagonist mecamylamine dose dependently blocked nicotine's (but not MA's) rate-decreasing effects on food-maintained behavior and (+)-epibatidine's discriminative-stimulus effects (e.g., Le Foll and Goldberg, 2009; Desai and Bergman, 2014). The effects of (+)-epibatidine also were moderately attenuated by the peripherally restricted $\mathrm{nAChR}$ antagonist hexamethonium, indicating that some peripheral nicotinic actions of epibatidine contributed to its discriminative-stimulus effects in the present studies. These findings contrast with previous studies (in both rodents and squirrel monkeys), in which hexamethonium did not alter the discriminative-stimulus effects of nicotine (Spealman et al., 1981; Stolerman et al., 1984). Although the particular aspect of epibatidine's peripheral actions that contributed to the present results are unknown, it is likely that the dissimilar results with hexamethonium across studies can be attributed to differences in the relative training doses of nicotine and epibatidine rather than 
TABLE 4

Doses of (+)-epibatidine alone and after pretreatment with mecamylamine, $\mathrm{DH} \beta \mathrm{E}, \mathrm{MLA}$, hexamethonium, varenicline and cytisine that were required to produce $50 \%$ increase in (+)-epibatidine lever responding.

Shown are $\mathrm{ED}_{50}$ values \pm S.E.M. (milligrams per kilogram); * represents significant effect of pretreatment drug vs. drug alone as determined by non-overlapping S.E.M. values. Values not determined were due to less than $50 \%(+)$-epibatidine lever responding.

\begin{tabular}{lcc}
\hline \multicolumn{1}{c}{ Treatment } & & $\mathrm{ED}_{50}$ value \pm S.E.M. \\
\cline { 3 - 3 } (+)-Epibatidine alone & $m g / k g$ \\
$+0.032 \mathrm{mg} / \mathrm{kg}$ Mecamylamine & $0.00040 \pm 0.000053$ \\
$+0.1 \mathrm{mg} / \mathrm{kg} \mathrm{Mecamylamine}$ & $0.00052 \pm 0.000044^{*}$ \\
$+0.32 \mathrm{mg} / \mathrm{kg}$ Mecamylamine & $0.00093 \pm 0.00015^{*}$ \\
$+0.032 \mathrm{mg} / \mathrm{kg} \mathrm{DH} \beta \mathrm{E}$ & $\mathrm{N} . \mathrm{D}$. \\
$+0.1 \mathrm{mg} / \mathrm{kg} \mathrm{DH} \beta \mathrm{E}$ & $0.00049 \pm 0.000058$ \\
$+0.32 \mathrm{mg} / \mathrm{kg} \mathrm{DH} \beta \mathrm{E}$ & $0.00069 \pm 0.00022^{*}$ \\
$+0.56 \mathrm{mg} / \mathrm{kg} \mathrm{DH} \beta \mathrm{E}$ & $0.00068 \pm 0.000081^{*}$ \\
$+0.01 \mathrm{mg} / \mathrm{kg}$ MLA & $\mathrm{N} . \mathrm{D}$. \\
$+0.032 \mathrm{mg} / \mathrm{kg}$ MLA & $0.00037 \pm 0.000088$ \\
$+0.056 \mathrm{mg} / \mathrm{kg}$ MLA & $0.00044 \pm 0.000090$ \\
$+0.1 \mathrm{mg} / \mathrm{kg}$ MLA & $0.00042 \pm 0.00010$ \\
$+1.0 \mathrm{mg} / \mathrm{kg}$ Hexamethonium & $0.00042 \pm 0.000094$ \\
$+3.2 \mathrm{mg} / \mathrm{kg}$ Hexamethonium & $0.00042 \pm 0.00010$ \\
$+5.6 \mathrm{mg} / \mathrm{kg}$ Hexamethonium & $0.00068 \pm 0.00030$ \\
$+0.001 \mathrm{mg} / \mathrm{kg}$ Varenicline & $0.00077 \pm 0.00017^{*}$ \\
$+0.0032 \mathrm{mg} / \mathrm{kg}$ Varenicline & $0.00058 \pm 0.000012^{*}$ \\
$+0.01 \mathrm{mg} / \mathrm{kg}$ Varenicline & $0.00032 \pm 0.00011$ \\
$+0.032 \mathrm{mg} / \mathrm{kg}$ Varenicline & $0.00027 \pm 0.00013$ \\
$+0.1 \mathrm{mg} / \mathrm{kg}$ Varenicline & $0.00021 \pm 0.000032$ \\
$+0.032 \mathrm{mg} / \mathrm{kg}$ Cytisine & N.D. \\
$+0.1 \mathrm{mg} / \mathrm{kg}$ Cytisine & $0.00049 \pm 0.000045$ \\
$+1.0 \mathrm{mg} / \mathrm{kg}$ Cytisine & $0.000095 \pm 0.000043^{*}$ \\
\hline
\end{tabular}

MLA, methyllycaconitine; N.D., not determined.

receptor-mediated differences in their peripherally mediated actions on skeletal muscle or in the autonomic nervous system.

If the $\alpha 4 \beta 2 \mathrm{nAChR}$ subtype was exclusively involved in the behavioral effects of nicotinic ligands, pretreatment with a selective antagonist at this receptor would be expected to produce full blockade of (+)-epibatidine and/or nicotine's behavioral effects. However, in the present study the $\alpha 4 \beta 2$ selective nicotinic antagonist $\mathrm{DH} \beta \mathrm{E}$ only moderately attenuated (+)-epibatidine's discriminative-stimulus effects and failed to antagonize the rate-decreasing effects of nicotine or (+)-epibatidine on food-reinforced behavior. These results are consistent with previous findings that the discriminativestimulus effects of nicotine but not its rate-decreasing effects are antagonized by $\mathrm{DH} \beta \mathrm{E}$ in nicotine-trained or MA-trained subjects (Stolerman et al., 1997; Gommans et al., 2000; Jutkiewicz et al., 2011; Desai and Bergman, 2014; also, see de Moura and McMahon, 2016). The limited and inconsistent antagonism by $\mathrm{DH} \beta \mathrm{E}$, in contrast to the robust and highly replicable antagonism produced by mecamylamine, strongly suggests that (+)-epibatidine, although characterized as an $\alpha 4 \beta 2$-selective agonist, produces its behavioral effects through other, or additional, subtypes of nAChR, i.e., heteromeric neuronal nAChR subunits containing $\beta 2$ subunits or the 10-fold less-selective $\alpha 3 \beta 4 \mathrm{nAChR}$ subtype (Avalos et al., 2002; Wei et al., 2003). With regard to the $\alpha 7 \mathrm{nAChR}$ subtype, the inability of MLA to significantly alter the discriminativestimulus effects of (+)-epibatidine adds to previous evidence indicating that the $\alpha 7 \mathrm{nAChR}$ subtype is not likely to play a



Fig. 5. Dose-effect functions of (+)-epibatidine alone or after pretreatment doses (10 minutes) of the partial nicotinic agonists varenicline (left panels) and cytisine (right panels). Effects on percent (+)-epibatidine-lever responding (top panels) and effects on response rates (bottom panels) are shown. Abscissa: drug dose (milligrams per kilogram). Ordinates: top panel: percentage (+)-epibatidine-lever responding; bottom panel: response rate.

major role in the stimulus effects of nicotinic agonists (Brioni et al., 1996).

Previous studies have suggested that varenicline and cytisine produce some nicotine-like stimulus effects but can attenuate nicotine's discriminative-stimulus effects in nicotine-trained and MA-trained subjects, presumably reflecting their partial agonist actions at the $\alpha 4 \beta 2 \mathrm{nAChR}$ subtype (e.g., LeSage et al., 2009; Jutkiewicz et al., 2011; Desai and Bergman, 2010, 2014). In the present studies, varenicline and cytisine, which are considered partial agonists, produced partial generalization for (+)-epibatidine and enhanced its stimulus effects and the rate-suppressant effects of nicotine. However, higher doses of these drugs did not antagonize the discriminative-stimulus effects of (+)-epibatidine or the response-rate decreasing effects of nicotine, as might be expected for partial agonists. In the absence of additional data, the reasons for the failure of these two drugs to display classic partial agonist activity when combined with fullnicotinic agonists remain unclear. Possibly, varenicline and cytisine do not have high enough affinity for nicotinic receptor subtypes to displace (+)-epibatidine or nicotine at the doses studied. Alternatively, these drugs also may be active at other nAChR subtypes (i.e., $\alpha 3 \beta 4$ ) that contributed to the behavioral effects of (+)-epibatidine and nicotine. Along these lines, the binding affinity profile of varenicline and cytisine at $\mathrm{nAChR}$ subtypes appears to differ from nicotine's affinity profile (see Table 2). For example, the relative affinity values for varenicline (0.08) and cytisine (0.28) compared with nicotine indicate 
that these drugs are approximately 12- and 4-fold more potent at $\alpha 4 \beta 2 \mathrm{nAChR}$ subtypes, respectively (see Table 2 ). However, at $\alpha 3 \beta 4 \mathrm{nAChR}$ subtypes, varenicline (2.51) appears to be about 2.5-fold less potent than nicotine, whereas cytisine (0.31) is approximately 3 -fold more potent than nicotine (see Table 2).

Notwithstanding limited pharmacological support from antagonism studies, we found a robust correspondence between the relative potencies with which nicotinic drugs [including those studied in Desai et al. (2016a)] on the one hand decrease food-reinforced responding and produce (+)-epibatidine-like stimulus effects, and on the other hand inhibit $\left[{ }^{3} \mathrm{H}\right]$ nicotine binding at $\alpha 4 \beta 2 \mathrm{nAChR}$ subtypes (Fig. 6, left panels). These results suggest a prominent role for the $\alpha 4 \beta 2 \mathrm{nAChR}$ in the behavioral effects of nicotine and other nicotinic drugs. Conversely, no correspondence was obtained between their relative behavioral potencies and relative potencies for inhibiting $\left[{ }^{125} \mathrm{I}\right]$ bungarotoxin binding at $\alpha 7 \mathrm{nAChRs}$ (Fig. 6, middle panels). Although these results provide further evidence that the $\alpha 7$ $\mathrm{nAChR}$ does not play a key role in the behavioral effects of nicotinic ligands, its involvement cannot be completely excluded since: 1) $\alpha 7$ antagonists have been reported to either increase (Brunzell and McIntosh, 2012) or decrease (Markou and Paterson, 2001) nicotine self-administration in rats, 2) actions at $\alpha 7 \mathrm{nAChRs}$ may be linked to the activation of other (e.g., $\beta 2 *$ ) nAChRs (Mameli-Engvall et al., 2006), and 3) $\alpha 7$ $\mathrm{nAChR}$ subtypes may be involved in long-term maintenance of nicotine use rather than the initial acquisition of nicotine consumption (Levin et al., 2009).

The $\alpha 3 \beta 4 \mathrm{nAChR}$ subtype also has received some attention regarding its possible role in the behavioral effects of nicotine (Toll et al., 2012). Activation of $\alpha 3 \beta 4 \mathrm{nAChRs}$ outside the brain previously has been associated with off-target effects of varenicline or cytisine that may interfere with and/or mask their ability to effectively attenuate persistent use of nicotine (Peng et al., 2013). However, nAChRs (e.g., $\alpha 3 \beta 4$ ) also have been identified in the medial habenula and ventral tegmental area, brain regions thought to be involved in nicotine's abuserelated effects (Gotti et al., 2006). Previously, we found that the relative potencies with which nicotine and the minor tobacco alkaloid anatabine produced reinforcing effects in monkeys corresponded better with their relative potencies for inhibiting binding to the $\alpha 3 \beta 4$ than the $\alpha 4 \beta 2 \mathrm{nAChR}$ subtype (Desai et al., 2016b). The close correspondence between the relative potencies of $\mathrm{nAChR}$ agonists in the present behavioral studies and in inhibiting $\left[{ }^{3} \mathrm{H}\right]$ epibatidine binding to the $\alpha 3 \beta 4$ nAChR subtype (Fig. 6, right panel) further suggests that this $\mathrm{nAChR}$ subtype may play a more significant role in the abuserelated effects of nicotine than once believed (Toll et al., 2012). Taken together, these data indicate the need for further critical evaluation of the role of the $\alpha 3 \beta 4 \mathrm{nAChR}$ subtype in the abuse-related behavioral effects of nicotine and other nicotinic drugs. However, the current lack of $\alpha 3 \beta 4$-selective agonists and antagonists precludes such evaluation. It is
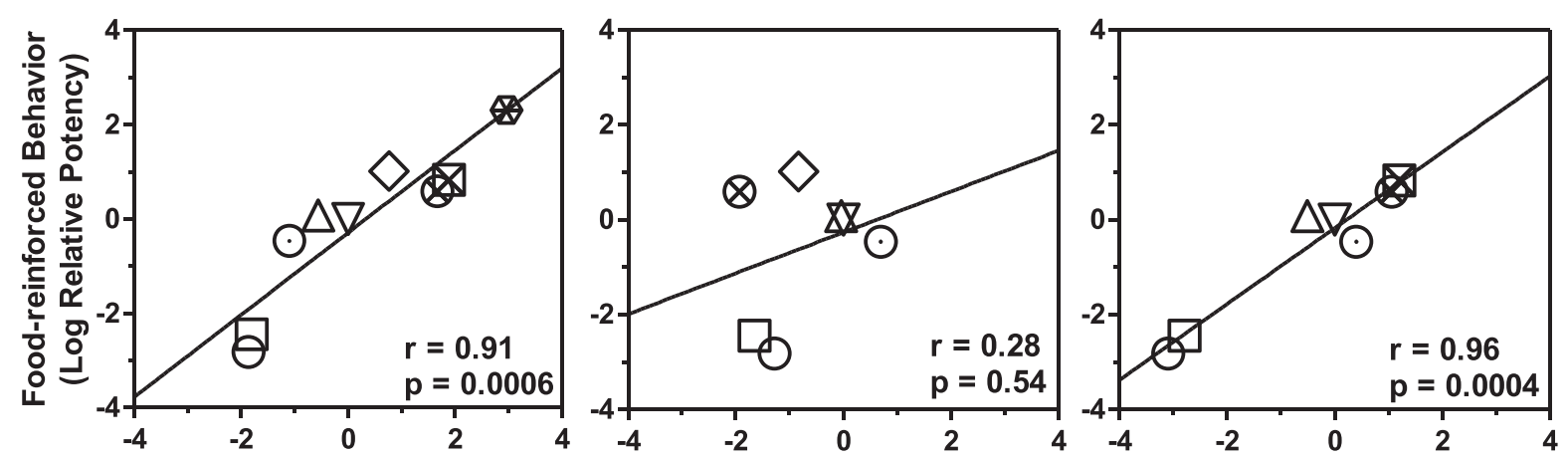

$\nabla$ Nic

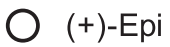

$\square(-)-E p i$
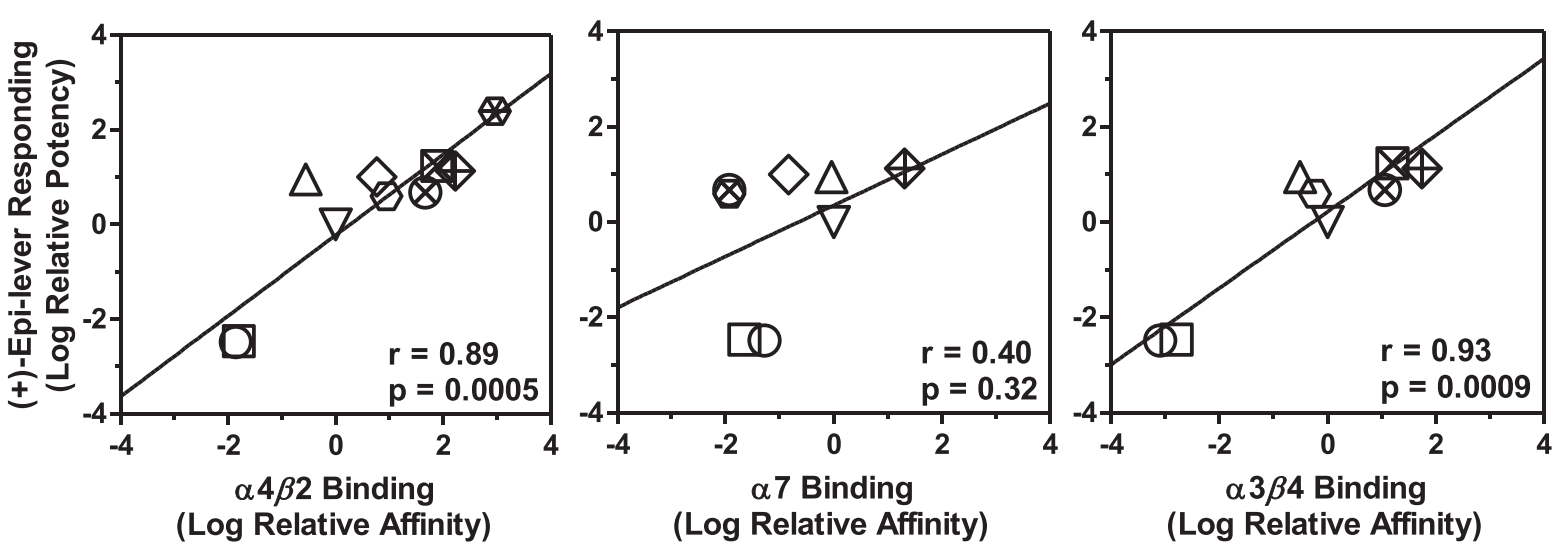

- Var

Anab

$\checkmark$ Nornic

$\nLeftarrow$ Iso

$\otimes$ Anabas

$\otimes$ Myo

Anat

Fig. 6. Correlation between relative potencies of nicotinic drugs [nicotine: Nic; (+)-epibatidine: (+)-Epi; (-)-epibatidine: (-)-Epi; cytisine: Cyt; varenicline: Var; anabaseine: Anab; nornicotine: Nornic; isoarecolone: Iso; anabasine: Anabas; myosimine: Myo; and anatabine: Anat] in the present studies and their relative affinities at $\alpha 4 \beta 2, \alpha 7$, and $\alpha 3 \beta 4 \mathrm{nAChRs}$ in radioligand binding studies (see Materials and Methods). Abscissae: affinity relative to nicotine for inhibiting binding of radioligand at $\alpha 4 \beta 2$ (left panels), $\alpha 7$ (middle panels), and $\alpha 3 \beta 4$ (right panels) nAChRs. Ordinates: potency relative to nicotine based on $\mathrm{ED}_{50}$ values for producing rate-decreasing effects on schedule-controlled behavior (Fig. 1; Table 1) and discriminativestimulus effects (Fig. 3; Table 1). Data for the relative affinities of two nicotinic agonists at $\alpha 7$ (anatabine, myosmine) and two at $\alpha 3 \beta 4$ (nornicotine, myosmine) $\mathrm{nAChRs}$ are unavailable; therefore, these nicotinic agonists were excluded from correlational analysis at these nAChR subtypes. 
noteworthy that other parameters (i.e., efficacy at nAChR subtypes) are also likely to play an important role in the behavioral profile of nicotinic agonists. Unfortunately, only limited in vitro efficacy information is currently available on a handful of nicotinic drugs at nAChR subtypes. Thus, it is not possible to meaningfully correlate in vitro efficacy data with our in vivo behavioral efficacy results.

In summary, there were three key findings. First, nicotinic agonists produced dose-related decreases in response rates for food-reinforced for behavior and, with the exception of lobeline, either fully or partially substituted for the $\alpha 4 \beta 2$-selective $\mathrm{nAChR}$ agonist (+)-epibatidine without appreciably altering response rates under the stimulus-termination schedule. These results suggest important differences in the effects of nicotinic agonists on FR rates of responding under the two schedule conditions. Second, the nonselective nicotinic antagonist mecamylamine antagonized both the discriminative-stimulus effects of (+)-epibatidine and nicotine's rate-decreasing effects, whereas the $\alpha 4 \beta 2$-selective nicotinic antagonist $\mathrm{Dh} \beta \mathrm{E}$ and the peripherally restricted nicotinic antagonist hexamethonium only slightly attenuated (+)-epibatidine discrimination and/or had no effect on the rate-altering effects of nicotine; the $\alpha 7$ selective nicotinic antagonist MLA did not alter (+)-epibatidine discrimination. Third, the smoking cessation medications varenicline and cytisine, presumed to be $\alpha 4 \beta 2$-selective partial agonists, only enhanced ( + )-epibatidine discrimination and the rate-decreasing effects of nicotine. Taken together, these results suggest that the behavioral effects of nicotinic ligands might not be exclusively mediated by $\alpha 4 \beta 2 \mathrm{nAChR}$ mechanisms and that a role for other $\mathrm{nAChR}$ subtypes deserves further consideration. Elucidating this role may lead to the identification of novel therapeutic targets and the development of candidate medications for smoking cessation.

\section{Acknowledgments}

We thank Dr. R.D. Spealman for comments on an earlier version of the manuscript.

\section{Authorship Contributions}

Participated in research design: Withey, Doyle, Desai.

Conducted experiments: Withey, Doyle.

Performed data analysis: Withey, Doyle, Desai.

Wrote or contributed to the writing of the manuscript: Withey, Doyle, Bergman, Desai.

\section{References}

Anderson DJ and Arneric SP (1994) Nicotinic receptor binding of $\left[{ }^{3} \mathrm{H}\right]$ cytisine, $\left[{ }^{3} \mathrm{H}\right]$ nicotine and $\left[{ }^{3} \mathrm{H}\right]$ methylcarbamylcholine in rat brain. Eur $J$ Pharmacol 253 261-267.

Avalos M, Parker MJ, Maddox FN, Carroll FI, and Luetje CW (2002) Effects of pyridine ring substitutions on affinity, efficacy, and subtype selectivity of neuronal nicotinic receptor agonist epibatidine. J Pharmacol Exp Ther 302:1246-1252.

Badio B and Daly JW (1994) Epibatidine, a potent analgetic and nicotinic agonist. Mol Pharmacol 45:563-569.

Barrett JE (1976) Effects of alcohol, chlordiazepoxide, cocaine and pentobarbital on responding maintained under fixed-interval schedules of food or shock presentation. J Pharmacol Exp Ther 196:605-615.

Beckmann JS, Meyer AC, Pivavarchyk M, Horton DB, Zheng G, Smith AM, Wooters TE, McIntosh JM, Crooks PA, Bardo MT, et al. (2015) r-bPiDI, an $\alpha 6 \beta 2^{*}$ nicotinic receptor antagonist, decreases nicotine-evoked dopamine release and nicotine reinforcement. Neurochem Res 40:2121-2130.

Benowitz NL (2010) Nicotine addiction. N Engl J Med 362:2295-2303.

Bergman J and Warren PH (1989) Effects of kappa opioids on schedule-controlled behavior of squirrel monkeys. $J$ Pharmacol Exp Ther 248:1102-1108.

Brioni JD, Kim DJ, and O'Neill AB (1996) Nicotine cue: lack of effect of the $\alpha 7$ nicotinic receptor antagonist methyllycaconitine. Eur J Pharmacol 301:1-5.

Brunzell DH and McIntosh JM (2012) Alpha7 nicotinic acetylcholine receptors modulate motivation to self-administer nicotine: implications for smoking and schizophrenia. Neuropsychopharmacology 37:1134-1143.
Cunningham CS, Javors MA, and McMahon LR (2012) Pharmacologic characterization of a nicotine-discriminative stimulus in rhesus monkeys. J Pharmacol Exp Ther 341:840-849.

Cunningham CS and McMahon LR (2011) The effects of nicotine, varenicline, and cytisine on schedule-controlled responding in mice: differences in $\alpha 4 \beta 2$ nicotinic receptor activation. Eur $J$ Pharmacol 654:47-52.

Damaj MI, Creasy KR, Grove AD, Rosecrans JA, and Martin BR (1994) Pharmacological effects of epibatidine optical enantiomers. Brain Res 664:34-40.

Damaj MI, Patrick GS, Creasy KR, and Martin BR (1997) Pharmacology of lobeline, a nicotinic receptor ligand. J Pharmacol Exp Ther 282:410-419.

Decker MW, Brioni JD, Bannon AW, and Arneric SP (1995) Diversity of neuronal nicotinic acetylcholine receptors: lessons from behavior and implications for CNS therapeutics. Life Sci 56:545-570.

de Fiebre CM, Meyer EM, Henry JC, Muraskin SI, Kem WR, and Papke RL (1995) Characterization of a series of anabaseine-derived compounds reveals that the 3-(4)-dimethylaminocinnamylidine derivative is a selective agonist at neuronal nicotinic alpha 7/125I-alpha-bungarotoxin receptor subtypes. Mol Pharmacol 47: 164-171.

de Moura FB and McMahon LR (2016) Differential antagonism and tolerance/crosstolerance among nicotinic acetylcholine receptor agonists: scheduled-controlled responding and hypothermia in C57BL/6J mice. Behav Pharmacol 27:240-248.

de Moura FB and McMahon LR (2017) The contribution of $\alpha 4 \beta 2$ and non- $\alpha 4 \beta 2$ nicotinic acetylcholine receptors to the discriminative stimulus effects of nicotine and varenicline in mice. Psychopharmacology (Berl) 234:781-792.

Desai RI and Bergman J (2010) Drug discrimination in methamphetamine-trained rats: effects of cholinergic nicotinic compounds. J Pharmacol Exp Ther 335: 807-816.

Desai RI and Bergman J (2014) Methamphetamine-like discriminative-stimulus effects of nicotinic agonists. J Pharmacol Exp Ther 348:478-488.

Desai RI and Bergman J (2015) Effects of the nanoparticle-based vaccine, SEL-068, on nicotine discrimination in squirrel monkeys. Neuropsychopharmacology 40: $2207-2216$

Desai RI, Doyle MR, Withey SL, and Bergman J (2016a) Nicotinic effects of tobacco smoke constituents in nonhuman primates. Psychopharmacology (Berl) 233: 1779-1789.

Desai RI, Sullivan KA, Kohut SJ, and Bergman J (2016b) Influence of experimental history on nicotine self-administration in squirrel monkeys Psychopharmacology (Berl), 233(12):2253-2263.

D'Souza MS and Markou A (2013) The "stop" and "go" of nicotine dependence: role of GABA and glutamate. Cold Spring Harb Perspect Med 3:a012146

Dukat M and Glennon RA (2003) Epibatidine: impact on nicotinic receptor research Cell Mol Neurobiol 23:365-378.

Dwoskin LP and Crooks PA (2002) A novel mechanism of action and potential use for lobeline as a treatment for psychostimulant abuse. Biochem Pharmacol 63:89-98.

Epping-Jordan MP, Picciotto MR, Changeux JP, and Pich EM (1999) Assessment of nicotinic acetylcholine receptor subunit contributions to nicotine selfadministration in mutant mice. Psychopharmacology (Berl) 147:25-26.

Etter JF, Lukas RJ, Benowitz NL, West R, and Dresler CM (2008) Cytisine for smoking cessation: a research agenda. Drug Alcohol Depend 92:3-8.

Faure P, Tolu S, Valverde S, and Naudé J (2014) Role of nicotinic acetylcholine receptors in regulating dopamine neuron activity. Neuroscience 282:86-100.

Ferretti G, Dukat M, Giannella M, Piergentili A, Pigini M, Quaglia W, Damaj MI, Martin BR, and Glennon RA (2003) Binding of nicotine and homoazanicotine analogues at neuronal nicotinic acetylcholinergic (nACh) receptors. Bioorg Med Chem Lett 13:733-735.

Fowler CD, Tuesta L, and Kenny PJ (2013) Role of $\alpha 5^{*}$ nicotinic acetylcholine receptors in the effects of acute and chronic nicotine treatment on brain reward function in mice. Psychopharmacology (Berl) 229:503-513.

Glick SD, Maisonneuve IM, and Kitchen BA (2002) Modulation of nicotine selfadministration in rats by combination therapy with agents blocking $\alpha 3 \beta 4$ nicotinic receptors. Eur J Pharmacol 448:185-191.

Goldberg SR, Risner ME, Stolerman IP, Reavill C, and Garcha HS (1989) Nicotine and some related compounds: effects on schedule-controlled behaviour and discriminative properties in rats. Psychopharmacology (Berl) 97:295-302.

Gommans J, Stolerman IP, and Shoaib M (2000) Antagonism of the discriminative and aversive stimulus properties of nicotine in C57BL/6J mice. Neuropharmacology 39:2840-2847.

Gotti C, Fornasari D, and Clementi F (1997) Human neuronal nicotinic receptors. Prog Neurobiol 53:199-237.

Gotti C, Zoli M, and Clementi F (2006) Brain nicotinic acetylcholine receptors: native subtypes and their relevance. Trends Pharmacol Sci 27:482-491.

Hahn B, Sharples CG, Wonnacott S, Shoaib M, and Stolerman IP (2003) Attentional effects of nicotinic agonists in rats. Neuropharmacology 44:1054-1067.

Harrod SB, Dwoskin LP, Green TA, Gehrke BJ, and Bardo MT (2003) Lobeline does not serve as a reinforcer in rats. Psychopharmacology (Berl) 165:397-404.

Hays JT, Ebbert JO, and Sood A (2008) Efficacy and safety of varenicline for smoking cessation. Am J Med 121 (Suppl 1):S32-S42.

Hughes JR, Shiffman S, Callas P, and Zhang J (2003) A meta-analysis of the efficacy of over-the-counter nicotine replacement. Tob Control 12:21-27.

Jensen AA, Mikkelsen I, Frølund B, Bräuner-Osborne H, Falch E, and KrogsgaardLarsen P (2003) Carbamoylcholine homologs: novel and potent agonists at neuronal nicotinic acetylcholine receptors. Mol Pharmacol 64:865-875.

Jutkiewicz EM, Brooks EA, Kynaston AD, Rice KC, and Woods JH (2011) Patterns of nicotinic receptor antagonism: nicotine discrimination studies. J Pharmacol Exp Ther 339:194-202.

Kem WR, Mahnir VM, Papke RL, and Lingle CJ (1997) Anabaseine is a potent agonist on muscle and neuronal alpha-bungarotoxin-sensitive nicotinic receptors. J Pharmacol Exp Ther 283:979-992.

Le Foll B and Goldberg SR (2009) Effects of nicotine in experimental animals and humans: an update on addictive properties. Handb Exp Pharmacol 192:335-367. 
LeSage MG, Shelley D, Ross JT, Carroll FI, and Corrigall WA (2009) Effects of the nicotinic receptor partial agonists varenicline and cytisine on the discriminative stimulus effects of nicotine in rats. Pharmacol Biochem Behav 91:461-467.

Levin ED, Petro A, Rezvani AH, Pollard N, Christopher NC, Strauss M, Avery J, Nicholson J, and Rose JE (2009) Nicotinic $\alpha 7$ - or $\beta 2$-containing receptor knockout: effects on radial-arm maze learning and long-term nicotine consumption in mice. Behav Brain Res 196:207-213.

Mameli-Engvall M, Evrard A, Pons S, Maskos U, Svensson TH, Changeux JP, and Faure P (2006) Hierarchical control of dopamine neuron-firing patterns by nicotinic receptors. Neuron 50:911-921.

Markou A and Paterson NE (2001) The nicotinic antagonist methyllycaconitine has differential effects on nicotine self-administration and nicotine withdrawal in the rat. Nicotine Tob Res 3:361-373.

Marks MJ, Stitzel JA, Romm E, Wehner JM, and Collins AC (1986) Nicotinic binding sites in rat and mouse brain: comparison of acetylcholine, nicotine, and alphabungarotoxin. Mol Pharmacol 30:427-436.

Matera C, Quadri M, Sciaccaluga M, Pomè DY, Fasoli F, De Amici M, Fucile S, Gotti C, Dallanoce C, and Grazioso G (2016) Modification of the anabaseine pyridine nucleus allows achieving binding and functional selectivity for the $\alpha 3 \beta 4$ nicotinic acetylcholine receptor subtype. Eur J Med Chem 108:392-405.

McGehee DS, Heath MJ, Gelber S, Devay P, and Role LW (1995) Nicotine enhancement of fast excitatory synaptic transmission in CNS by presynaptic receptors. Science 269:1692-1696.

Miller DK, Harrod SB, Green TA, Wong MY, Bardo MT, and Dwoskin LP (2003) Lobeline attenuates locomotor stimulation induced by repeated nicotine administration in rats. Pharmacol Biochem Behav 74:279-286.

Mukhin AG, Gündisch D, Horti AG, Koren AO, Tamagnan G, Kimes AS, Chambers J, Vaupel DB, King SL, Picciotto MR, et al. (2000) 5-Iodo-A-85380, an $\alpha 4 \beta 2$ subtypeselective ligand for nicotinic acetylcholine receptors. Mol Pharmacol 57:642-649.

National Academy of Sciences (2011) Guide for the Care and Use of Laboratory Animals, 8th edn. The national academies press: Washington, D.C. www.nap.edu.

Parker MJ, Beck A, and Luetje CW (1998) Neuronal nicotinic receptor $\beta 2$ and $\beta 4$ subunits confer large differences in agonist binding affinity. Mol Pharmacol 54: 1132-1139.

Peng C, Stokes C, Mineur YS, Picciotto MR, Tian C, Eibl C, Tomassoli I, Guendisch D, and Papke RL (2013) Differential modulation of brain nicotinic acetylcholine receptor function by cytisine, varenicline, and two novel bispidine compounds: emergent properties of a hybrid molecule. J Pharmacol Exp Ther 347:424-437.

Picciotto MR, Zoli M, Rimondini R, Léna C, Marubio LM, Pich EM, Fuxe K, and Changeux JP (1998) Acetylcholine receptors containing the $\beta 2$ subunit are involved in the reinforcing properties of nicotine. Nature 391:173-177.

Pons S, Fattore L, Cossu G, Tolu S, Porcu E, McIntosh JM, Changeux JP, Maskos U, and Fratta W (2008) Crucial role of $\alpha 4$ and $\alpha 6$ nicotinic acetylcholine receptor subunits from ventral tegmental area in systemic nicotine self-administration. J Neurosci 28:12318-12327.

Quarta D, Ciruela F, Patkar K, Borycz J, Solinas M, Lluis C, Franco R, Wise RA, Goldberg SR, Hope BT, et al. (2007) Heteromeric nicotinic acetylcholine-dopamine autoreceptor complexes modulate striatal dopamine release. Neuropsychopharmacology 32:35-42.

Rollema H, Chambers LK, Coe JW, Glowa J, Hurst RS, Lebel LA, Lu Y, Mansbach RS, Mather RJ, Rovetti CC, et al. (2007) Pharmacological profile of the $\alpha 4 \beta 2$ nicotinic acetylcholine receptor partial agonist varenicline, an effective smoking cessation aid. Neuropharmacology 52:985-994.

Rollema H, Shrikhande A, Ward KM, Tingley FD, III, Coe JW, O'Neill BT, Tseng E, Wang EQ, Mather RJ, Hurst RS, et al. (2010) Pre-clinical properties of the $\alpha 4 \beta 2$ nicotinic acetylcholine receptor partial agonists varenicline, cytisine and dianicline translate to clinical efficacy for nicotine dependence. Br J Pharmacol 160:334-345.

Sanjakdar SS, Maldoon PP, Marks MJ, Brunzell DH, Maskos U, McIntosh JM Bowers MS, and Damaj MI (2015) Differential roles of $\alpha 6 \beta 2^{*}$ and $\alpha 4 \beta 2^{*}$ neuronal nicotinic receptors in nicotine- and cocaine-conditioned reward in mice. Neuropsychopharmacology 40:350-360.
Schmitt JD, Sharples CG, and Caldwell WS (1999) Molecular recognition in nicotinic acetylcholine receptors: the importance of $\pi$-cation interactions. $J$ Med Chem 42 : 3066-3074.

Shoaib M (2006) Effects of isoarecolone, a nicotinic receptor agonist in rodent models of nicotine dependence. Psychopharmacology (Berl) 188:252-257.

Smith JW and Stolerman IP (2009) Recognising nicotine: the neurobiological basis of nicotine discrimination. Handb Exp Pharmacol 192:295-333.

Spealman RD, Goldberg SR, and Gardner ML (1981) Behavioral effects of nicotine: schedule-controlled responding by squirrel monkeys. J Pharmacol Exp Ther 216 484-491.

Stolerman IP, Chandler CJ, Garcha HS, and Newton JM (1997) Selective antagonism of behavioural effects of nicotine by dihydro-beta-erythroidine in rats. Psychopharmacology (Berl) 129:390-397.

Stolerman IP, Garcha HS, and Mirza NR (1995) Dissociations between the locomotor stimulant and depressant effects of nicotinic agonists in rats. Psychopharmacology (Berl) 117:430-437.

Stolerman IP, Garcha HS, Pratt JA, and Kumar R (1984) Role of training dose in discrimination of nicotine and related compounds by rats. Psychopharmacology (Berl) 84:413-419.

Sullivan JP, Decker MW, Brioni JD, Donnelly-Roberts D, Anderson DJ, Bannon AW, Kang CH, Adams P, Piattoni-Kaplan M, Buckley MJ, et al. (1994) (+/-)-Epibatidine elicits a diversity of in vitro and in vivo effects mediated by nicotinic acetylcholine receptors. J Pharmacol Exp Ther 271:624-631.

Tapper AR, McKinney SL, Nashmi R, Schwarz J, Deshpande P, Labarca C, Whiteaker P, Marks MJ, Collins AC, and Lester HA (2004) Nicotine activation of $\alpha 4^{*}$ receptors: sufficient for reward, tolerance, and sensitization. Science 306: 1029-1032.

Toll L, Zaveri NT, Polgar WE, Jiang F, Khroyan TV, Zhou W, Xie XS, Stauber GB, Costello MR, and Leslie FM (2012) AT-1001: a high affinity and selective $\alpha 3 \beta 4$ nicotinic acetylcholine receptor antagonist blocks nicotine self-administration in rats. Neuropsychopharmacology 37:1367-1376.

Vierck CJ, Hansson PT, and Yezierski RP (2008) Clinical and pre-clinical pain assessment: are we measuring the same thing? Pain 135:7-10.

Walker N, Howe C, Glover M, McRobbie H, Barnes J, Nosa V, Parag V, Bassett B and Bullen C (2014) Cytisine versus nicotine for smoking cessation. N Engl J Med 371:2353-2362.

Watkins SS, Epping-Jordan MP, Koob GF, and Markou A (1999) Blockade of nicotine self-administration with nicotinic antagonists in rats. Pharmacol Biochem Behav 62:743-751.

Wei ZL, Xiao Y, George C, Kellar KJ, and Kozikowski AP (2003) Functionalization of the alicyclic skeleton of epibatidine: synthesis and nicotinic acetylcholine receptor binding affinities of epibatidine analogues. Org Biomol Chem 1:3878-3881.

Xiao Y and Kellar KJ (2004) The comparative pharmacology and up-regulation of rat neuronal nicotinic receptor subtype binding sites stably expressed in transfected mammalian cells. J Pharmacol Exp Ther 310:98-107.

Xiao Y, Meyer EL, Thompson JM, Surin A, Wroblewski J, and Kellar KJ (1998) Rat $\alpha 3 / \beta 4$ subtype of neuronal nicotinic acetylcholine receptor stably expressed in a transfected cell line: pharmacology of ligand binding and function. Mol Pharmacol 54:322-333.

Yenugonda VM, Xiao Y, Levin ED, Rezvani AH, Tran T, Al-Muhtasib N, Sahibzada N, Xie T, Wells C, Slade S, et al. (2013) Design, synthesis and discovery of picomolar selective $\alpha 4 \beta 2$ nicotinic acetylcholine receptor ligands. J Med Chem 56: 8404-8421.

Address correspondence to: Rajeev I. Desai, Preclinical Pharmacology Laboratory, Department of Psychiatry, Harvard Medical School/Mclean Hospital, 115 Mill Street, Belmont, MA 02478. E-mail: rdesai@mclean. harvard.edu 